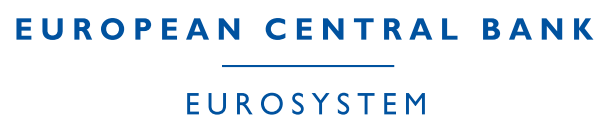

WORIING PAPER SERIES NO 1508 I JANUARY 2013

Matthieu Darracq-Paries and Roberto De Santis

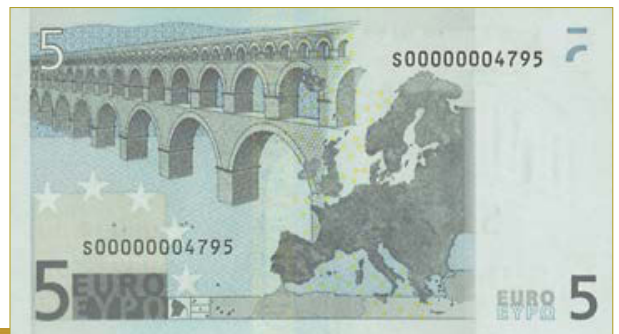

In 2013 all ECB

publications
feature a motif

taken from the €5 banknote

NOTE: This Working Paper should not be reported as representing the views of the European Central Bank (ECB). The views expressed are those of the authors and do not necessarily reflect those of the ECB. 


\section{Matthieu Darracq-Paries}

European Central Bank; e-mail: matthieu.darracq_paries@ecb.europa.eu

\section{Roberto De Santis}

European Central Bank; e-mail: roberto.de_santis@ecb.europa.eu

(c) European Central Bank, 2013

$\begin{array}{ll}\text { Address } & \text { Kaiserstrasse 29, 60311 Frankfurt am Main, Germany } \\ \text { Postal address } & \text { Postfach } 1603 \text { 19, 60066 Frankfurt am Main, Germany } \\ \text { Telephone } & +496913440 \\ \text { Internet } & \text { http://www.ecb.europa.eu } \\ \text { Fax } & +496913446000\end{array}$

All rights reserved.

$\begin{array}{ll}\text { ISSN } & \text { 1725-2806 (online) } \\ \text { EU Catalogue No } & \text { QB-AR-13-005-EN-N (online) }\end{array}$

Any reproduction, publication and reprint in the form of a different publication, whether printed or produced electronically, in whole or in part, is permitted only with the explicit written authorisation of the ECB or the authors.

This paper can be downloaded without charge from http://www.ecb.europa.eu or from the Social Science Research Network electronic library at http://ssrn.com/abstract_id=2204282.

Information on all of the papers published in the ECB Working Paper Series can be found on the ECB's website, http://www.ecb. europa.eu/pub/scientific/wps/date/html/index.en html 


\begin{abstract}
The identification of non-standard monetary policy shocks is a key challenge for econometricians, not least as these measures are somewhat unprecedented in modern central banking history and as the instruments vary widely across the various non-standard measures. This paper focuses on the 3-year long-term refinancing operations (LTROs), implemented by the ECB in December 2011 and February 2012. The macroeconomic impact of this measure is identified using the April 2012 Bank Lending Survey (BLS) as well as the special ad-hoc questions on the LTROs conducted in mid-February 2012. We estimate a panel-VAR for the euro area countries, which include relevant BLS variables, and identify credit supply shocks both recursively and with sign restriction methods. The macroeconomic effects of the 3-year LTROs are associated with the favorable credit supply shocks extracted through BLS information for the first half of 2012. Compared with the most likely developments one could have expected at the end of 2011 when financial tensions culminated, our counterfactual exercises suggest that the 3-year LTROs significantly lifted prospects for real GDP and loan provision to non-financial corporations over the next two-to-three years.
\end{abstract}

Keywords: Non-standard monetary policy measures, panel VAR.

JEL classification: C23, E52. 


\section{Non-Technical Summary}

In the second half of 2011, the euro area sovereign debt crisis exacerbated, funding and deleveraging pressures on euro area banks raised the risk of credit supply disruptions affecting the financing of firms and households. Against this background, the ECB increased the length of the refinancing operations with fixed rate tenders and full allotment in December 2011 and February 2012 to 3-years with the aim to support bank lending and counteract the risks of disorderly bank deleveraging process.

This study aims at assessing the macroeconomic implications of the 3-year longterm refinancing operations (LTROs) conducted by the ECB in December 2011 and February 2012, identifying the implied non-standard monetary policy shock through the Bank Lending Survey (BLS) information for the beginning of 2012. The empirical analysis on the impact of the 3-year LTROs assumes that the main transmission channel of this non-standard monetary policy measure works through the mitigation of liquidity and funding risks in the euro area banking system. This ultimately contributes to prevent any disorderly deleveraging process and supports the financing of the economy at large. More specifically, the BLS suggests that non-standard liquidity measures have been successful in limiting the tightening of credit standards to households and firms due to liquidity risks and access to funding. This also supports the view that the 3-year LTROs can be interpreted as a favorable credit supply shock.

Compared with the most likely developments one could have expected at the end of 2011 when financial tensions culminated, the model-based counterfactual experiments suggest that the 3-year LTROs are expansionary and associated with increases in GDP, loan volume to non-financial corporations and a compression of lending rate spreads over a two-to-three year horizon. The economic support of the non-standard measure is only gradually reflected in loan dynamics while the benefits on output materialize earlier. Moreover, given the moderate response of spreads compared to loans, the 3-year LTROs are estimated to importantly act on the economy through quantitative credit easing.

Overall, our paper brings an empirical contribution to the literature on the effectiveness of unconventional monetary policy at times of financial distress. The quantitative findings show that in the presence of acute tensions, exceptional central bank liquidity measures could help supporting the provision of bank lending to the economy and avoid an abrupt dry-up of credit supply. This assessment is consistent with the view that non-standard monetary policy measures like the one analyzed in this paper are complementary to interest rate decisions and are essentially predicated on the basis of emerging financial frictions in the credit intermediation sector. 
The success of the 3-year LTROs in reducing funding risk in the banking sector can also be demonstrated by the developments of the 3-month EURIBOS-OIS spread in the first half of 2012. Despite the renewed tensions in some euro area sovereign debt markets in the second quarter of 2012 owing to several country-specific factors, this measure of interbank credit risk declined from 100 basis points on the day of announcement (8 December 2011) to 40 basis points at the end of March 2012 and fluctuated around it since then until the speech on the convertibility risk by the ECB President Draghi on 26 July 20012. After the speech, the interbank credit risk continued its declining trend reaching 12 basis points on 26 November 2012; such low level was obtained on 8 August 2007, the day before the ECB had to cope with the first signal of dislocation of the money market.

This money market resilience is consistent with the fact that bank funding risks were effectively reduced by the ECB measures announced on 8 December 2011, because the 3-year LTROs provided a window of opportunity for banks to deleverage in a more orderly fashion and to increase their liquidity and capital buffers in a sustainable manner. 


\section{Introduction}

The identification of non-standard monetary policy shocks is still an uncharted territory. Identifying non-standard monetary policy shocks is a key challenge for econometricians, not least as these measures are somewhat unprecedented in modern central banking history and as the instruments vary widely across the various non-standard measures. An extensive theoretical literature has discussed the various policy alternatives, when the policy rate hit the zero lower bound. By contrast, the empirical literature is only gradually emerging as data are collected and solutions to identification issues are found.

A growing number of empirical papers have focused on the impact of non-standard measures on asset prices through portfolio balance effects. There is no doubt that policy measures have reduced bond yields, particularly when they are announced. However, the first-order objective of the non-standard measures is to support the financial intermediation process to avoid the mistakes of the early 1930s.

In fact, the European Central Bank (ECB) non-standard monetary policy measures implemented through the crisis are complementary to interest rate decisions and are essentially predicated on the basis of emerging financial frictions in the credit intermediation sector which impair the monetary policy transmission mechanism.

Bernanke et al. (2004) and Cecioni, et al. (2011) provide an extensive survey of the theoretical and empirical literature before and after the collapse of Lehman Brothers, respectively. Therefore, the details of the policy measures and the alternative theoretical approaches to the various issues are discussed elsewhere. Here, we focus on the impact of non-standard liquidity measures introduced by the ECB, with the 3-year long-term refinancing operations (LTROs) implemented in December 2011 and February 2012. On 21 December 2011, the ECB allotted EUR 489 billion (USD 644 billion) in three-year loans to 523 banks; on 29 February 2012, the ECB allotted EUR 530 billion (USD 713 billion) in similar loans to 800 lenders.

We identify the implied non-standard monetary policy shock through $(i)$ the adhoc Bank Lending Survey (BLS) questionnaire collected between 9 and 15 February 2012, which provides the bank answers on the effect of the 3-year LTROs over the first half of 2012, and (ii) the BLS conducted in March and published in April 2012, reporting actual survey information for the first quarter of 2012 and expected values for the second quarter of 2012. Both surveys and in particular the special ad-hoc BLS question on the 3-year LTROs show that this non-standard measure has been successful in making less tight credit standards to both households and non-financial corporations in the euro area. 
Following Ciccarelli, et al. (2010), who suggest employing the euro area BLS demand and supply factors to non-financial corporations to identify credit supply shocks, we estimate a panel VAR using Generalized Method of Moments (GMM) and the Arellano-Bond estimator to overcome the Nickell (1981) bias in dynamic panels. The model is estimated using quarterly series over the period 2003Q1-2011Q4 for the largest eleven euro area countries or for eight countries excluding Greece, Ireland and Portugal, which are under the financial assistance program. The main advantage of the shorter sample period, which is due to BLS-data availability, is that our results are less subject to the Lucas critique (that is, historical relationships are prone to break down in novel circumstances) as the model is estimated starting from the pre-crisis common expansionary cycle, which is behind the recent global economic and financial crisis.

Based on the estimated panel-VAR, the macroeconomic impact of the 3-year LTROs is computed in two steps. First, regarding the identification of credit supply shocks, we use two alternative methods based on short-run exclusion restrictions: the recursive (Sims, 1980) and the sign restriction (Uhlig, 2005; Rubio-Ramirez, Waggoner, Zha, 2010). The two identification schemes implemented in the paper deliver comparable macroeconomic propagation of credit supply disturbances and similar explanatory power on euro area economic developments through the crisis. Such similarities are worth emphasizing given the strong conceptual and technical differences between the two identification strategies.

Second, the effect of the 3-year LTROs is assumed to be exclusively attributed to the credit supply shocks estimated for the first half of 2012 either using the unpublished ad-hoc questionnaire of the BLS in February 2012 or the published April 2012 survey round. The results based on both surveys and alternative identification schemes turn out to be strikingly similar. The counterfactual experiment points to a hump-shaped response of euro area real GDP in level reaching a peak by mid-2013 at $0.5-0.8$ percentage points depending on data used to identify the shock and identification methods. By end-2014, real GDP remains significantly above baseline. The effects on inflation materialize with some lag with the annual inflation rate increasing by $0.15-0.25$ percentage points at the peak in the beginning of 2014. Turning to credit variables, the outstanding amount of bank loans to non-financial corporations responds very gradually with maximum effects recorded in the second half of 2014, almost two years later than for GDP, at around 1.7-2.5 percentage points above baseline. At the same time, the lending rate spread declines by $10-20$ basis points in the first quarters, reverting back to zero by mid-2014. 
The empirical analysis on the impact of the 3-year LTROs assumes that the main transmission channel of this non-standard monetary policy measure works through the mitigation of liquidity and funding risks in the euro area banking system which ultimately contributes to relax bank lending standards and supports the financing of the economy at large. The moderate narrowing of lending rate spreads compared with the improvement of economic activity and loan provision suggests that the relaxation of credit standards due to the 3-year LTROs is more related to a quantitative easing of loan supply. The converging outcomes obtained regardless of the data and identification methods used reinforce the plausibility of our interpretation that 3-year LTROs acted as a favorable credit supply shock.

We also provide alternative counterfactual experiments in order to assess the robustness of the mentioned results. We replace in the panel-VAR the BLS variable on credit standards by the aggregation of three factors explaining credit standards in the BLS questionnaire: banks' liquidity position, banks' capital position and banks' ability to access market financing. Focusing the credit supply indicators on the most acute sources of bank vulnerabilities during the financial crisis is supportive of the qualitative results mentioned previously, even increasing our measurement of the effectiveness of ECB's non-standard measures.

We also broaden the impact assessment of the 3-year LTRO beyond its effect on the bank lending transmission channel by incorporating in the panel-VAR financial variables likely to capture factors related to economic risk perception and risk aversion. A popular indicator used in the macro-financial empirical literature is the VIX, an index of stock market option-implied volatility. This exercise shows that the quantitative assessment would not significantly change by controlling for financial variables in the panel-VAR system or broadening the transmission channel of the 3-year LTROs to risk aversion and uncertainty.

Turning to the closely related literature, the effects of the non-standard measures introduced by the ECB on macroeconomic variables computed using VAR methods are also studied by Lenza, et al. (2010), Peersman (2011), Giannone, et al. (2012) and Gambacorta, et al. (2012). Lenza, et al. (2010) and Giannone, et al. (2012) study the impact of the non-standard measures by employing counterfactual simulations, which resemble generalized impulse response functions. Peersman (2011) and Gambacorta, et al. (2012) instead make use of structural VARs with sign restrictions. ${ }^{1}$

\footnotetext{
${ }^{1}$ Lenza, et al. (2010) identify the non-standard measure shock indirectly assuming that the reduction in the spread between unsecured and secured money market rates observed between November 2008 and August 2009 was entirely due to the non-standard measures. Giannone, et al. (2012)
} 
Specifically, Peersman (2011) suggests to identify the non-standard measures using bank loans. The non-standard monetary policy shock is identified as the innovation to credit supply (i.e. higher bank loans with lower lending rates) orthogonal to the policy rate innovations. The transmission of such shock does not have the same feature of the transmission of a standard monetary policy shock. It has the same humpshaped response of output and a permanent but delayed response of prices, with the propagation being generally more sluggish, but an expansionary shock passes on the bank lending through a decline in the lending rate spreads of banks, while this spreads increases significantly after a fall in the policy rate. The impact of the non-standard policy shock estimated by Peersman (2011) has the same transmission mechanism of his credit multiplier shock, which is an innovation that shifts the supply of bank loans, and our credit supply shock estimated using the BLS credit tightening information.

Gambacorta, et al. (2012), following the approach used by Peersman (2011), identify the non-standard measure using directly the central bank balance sheets and estimating a panel of eight advanced economies since the onset of the global financial crisis. To identify the shock, they assume that an unexpected increase in central banks' liquidity supply is associated with unexpected lower aggregate financial market volatility measured by the implied stock market volatility index (VIX). By means of such identification scheme, they show that an exogenous increase in central bank balance sheet at the zero lower bound is expansionary, but this is also because a lower VIX is generally associated with better economic perspectives.

The rest of the paper is structured as follows. In Section 2, we discuss the VAR method and data. Section 3 shows the relative importance of the credit supply shock on the euro area macroeconomic variables under alternative identification strategy. Section 4 discusses the key results focusing on the macroeconomic impact of the identified non-standard 3-years LTROs shock. Section 5 concludes.

instead makes use of the ECB bank balance sheet. By comparing the forecasts of the main macro variables conditional to the observed path of the ECB bank balance sheet and a no-policy scenario in which the ECB balance sheet is projected to develop conditional to the macroeconomic environment, they conclude that in the absence of the ECB intervention, the macroeconomic activity in the euro area would have been more depressed. This identification scheme has two shortcomings: (1) the forecast of the ECB balance sheet is conditional to a macroeconomic environment that has already been affected by the policy measure; (2) the comparison of the two scenarios is comparable to a generalized impulse response function rather than an impulse from an identified structural shock. 


\section{A panel-VAR using the Bank Lending Survey infor- mation}

The model can be written as

$$
y_{i, t}=\gamma_{i}+B(L) y_{i, t-1}+\varepsilon_{i, t}, \quad t=1, \ldots, T,
$$

where $y_{i, t}$ is a $k \times 1$ vector of variables of each of the $i$ countries, $i=1, \ldots I, \gamma_{i}$ is an individual-specific, unobservable, fixed effect and $B(L)$ is a lag polynomial with the VAR coefficients. The disturbances, $\varepsilon_{i, t}$, have zero means and variance, $\sum=\mathbf{E}\left[\varepsilon_{i, t}, \varepsilon_{i, t}^{\prime}\right]$.

The presence of $\gamma_{i}$ and $y_{i, t-1}$ make least square estimation of equation (1) inconsistent, even if the disturbances, $\varepsilon_{i, t}$, are uncorrelated, particularly when the time span is small (Nickell, 1981). In such cases, the instrumental variable (IV) estimator (Anderson and Hsiao, 1981) and generalized method of moments (GMM) estimator (Arellano and Bond, 1991) are both widely used. As noted by Blundell and Bond (1998), these estimators suffer from a weak instrument problem when the dynamic panel autoregressive coefficient approaches unity. This is not the case in our VAR specification (see next sub-section).

The standard fixed effect estimator is biased in VAR with panel data (Holtz-Eakin, et al., 1988). Therefore, we estimate the panel assuming fixed effects and common slopes and adopting the Arellano-Bond GMM estimator. Equation (1) is estimated in first differences, using as instrument lagged levels of the dependent variable:

$$
E\left[y_{i, t-j}\left(\Delta y_{i, t}-B(L) \Delta y_{i, t-1}\right)\right]=0, \quad s=2,3, \ldots, t .
$$

It is important to stress that variables lagged twice are used as instrument for the first-differenced equation.

\subsection{The data set}

We bring the model to the data by considering historical series of quarterly data for the euro area over the period 2003Q1 to 2011Q4 for the largest eleven euro area countries. The size of T depends on BLS data availability, as the survey was conducted for the first time in 2003Q1. The size of $\mathrm{N}$ depends on the number of countries that joined the euro area as of 2003Q1 with the exclusion of Luxemburg: Austria, Belgium, Finland, France, Germany, Greece, Ireland, Italy, Netherlands, Portugal and Spain.

Economic activity is measured by quarter-on-quarter real GDP growth, while inflation is measured by quarter-on-quarter GDP deflator inflation. As for the monetary 
policy stance, it is common to employ the EONIA (Euro OverNight Index Average) rate (see Cicarelli, et al., 2010). ${ }^{2}$ The EONIA is a weighted average of overnight Euro Interbank Offer Rates for inter-bank loans. In mid-2011, the very high demand for overnight liquidity by banks pushed the EONIA rate above the EURIBOR, which is the rate at which euro area banks lend to each other on an unsecured basis. Conversely, the 3-month OIS (Overnight Index Swap) rate, which is an interest rate swap whose floating leg is tied to an overnight rate, does not suffer from sharp movement due to technical reasons. Therefore, it is a preferable rate to measure the monetary policy stance (see Figure 1).

[insert Figure 1 here]

As for bank intermediation, given that the BLS credit conditions to NFCs, are useful to identify the credit supply shock, we employ BLS demand and supply factors to NFCs as well as quarter-on-quarter loan growth to NFCs and the spread between the lending rate to NFCs and the 3-month OIS.

The BLS is addressed to senior loan officers of a representative sample of euro area banks and is conducted four times a year. The sample group participating in the survey comprises around 90-100 banks from all euro area countries and takes into account the characteristics of their respective national banking structures. The survey contains 17 specific questions on past and expected credit market developments. The former covers developments over the past three months, while the latter focus on the next three months. Questions are classified according to the two borrower sectors that are the central focus of the survey, i.e. enterprises and households. The definitions and classifications used in the survey are consistent with other ECB statistics. For both enterprises - i.e. non-financial corporations - and households, the questionnaire covers both loan demand and loan supply factors. Among the supply factors, attention is given to credit standards and credit conditions and terms, as well as to the various factors that may be responsible for their changes. Credit standards are the internal guidelines or criteria that guide a bank's loan policy. The terms and conditions of a loan refer to the specific obligations agreed upon by the lender and the borrower, such as the interest rate, collateral required and maturity. All in all, ten questions centre on supply factors, of which seven look at credit standards and three at terms and conditions. Of the questions on credit standards, three refer to

\footnotetext{
${ }^{2}$ Ciccarelli et al (2010) used four-quarter sum real GDP growth and inflation. This approach, however, generates more persistence in the impulse response functions and, as a result, in the historical decomposition of shocks.
} 
banks' liquidity position, access to market funding and capital position, which are the most acute sources of bank vulnerabilities during the financial crisis affecting credit supply. We will also make use of this more restrictive definition of BLS credit supply factor to identify the credit supply shocks. Among the factors that may affect loan demand, various factors related to financing needs and the use of alternative finance are mentioned. Seven questions focus explicitly on loan demand, of which three look at demand from enterprises and four at demand from households. Overall, 13 backward and four forward-looking questions are included, in order to capture both recent and expected developments.

The BLS demand and supply factors to NFCs for the euro area as a whole as well as for the individual countries that have allowed publication are plotted in Figure 2. The net percentage for the questions on supply of loans refers to the difference between the sum of the percentages for "tightened considerably" and "tightened somewhat" and the sum of the percentages for "eased somewhat" and "eased considerably". The net percentages for the questions on demand for loans are defined as the difference between the sum of the percentages for "increased considerably" and "increased somewhat" and the sum of the percentages for "decreased somewhat" and "decreased considerably". The BLS credit standards were tightened twice in 2007-2008 period and with the buildup of the euro area sovereign debt crisis in 2010-2011 period. The results of the BLS disaggregated at the level of individual countries suggest that credit conditions in 2011 were particularly tight in Italy and Portugal. The 3-year LTROs policy introduced by the ECB in December 2011 and February 2012 was very effective: according to the April 2012 BLS, the net tightening of credit standards by Italian and Portuguese banks declined substantially in 2012Q1, both for loans to non-financial corporations and for loans to households. Similarly, the lending rates to NFCs stabilized after the introduction of the 3-year LTROs policy. This change mainly reflected milder pressures from cost of funds and balance sheet constraints, especially banks' access to funding and their liquidity position.

\section{[insert Figure 2 here]}

The average correlation among the variables is in most cases strongly statistically significant (see Table 1), which suggests that the VAR methodology is needed to extract the expected correlations useful to identify the "surprises". As for the lag length, the Schwarz information criterion suggests the use of one lag.

[insert Table 1 here] 


\subsection{Panel unit root tests}

Given that the traditional GMM estimator works very badly if the variables are I(1), we report in Table 2 a buttery of unit root tests. For purposes of testing, there are two natural assumptions that we can make about the autoregressive coefficient. First, one can assume that the persistence parameters are common across cross-sections, as employed by Breitung (2000), Hadri (2000) and Levin, et al. (2002). Alternatively, one can allow the unit root processes to vary freely across cross-sections, as suggested by Maddala and Wu (1999), Choi (2001) and Im, et al. (2003). All tests, but Hadri (2000), employ a null hypothesis of a unit root, while the Hadri test uses a null of no unit root. Except for the 3-month OIS and the lending rate spread, the unit root hypothesis is highly rejected. The non-stationarity of the policy rate and the lending rate spread is simply due to the very high persistence of both time series (see Figure 1). Therefore, we can assume them stationary. It would be unrealistic to believe that such rates were non-stationary.

\section{[insert Table 2 here]}

\section{Credit supply shocks and economic fluctuations}

In this section, we identify credit supply shocks in the panel-VAR and analyze the macroeconomic propagation mechanism of such economic disturbances together with their contribution to euro area cyclical developments over the last decade.

\subsection{Impulse response function of a credit supply shock}

Structural interpretation of VAR models requires additional identifying assumptions. We use thereafter two alternative short-run exclusion restriction methods: a traditional recursive identification scheme and one based on sign restrictions.

\subsubsection{Recursive identification}

Error terms of a VAR are typically correlated across equations. By computing the Cholesky factorization of the reduced form VAR covariance matrix $\sum$, we "orthogonalize" the reduced-form innovations and estimate the structural shocks (Sims, 1980). Specifically, once estimated $\mathbf{B}(L)$, we can recover the disturbances, $\varepsilon_{i, t}$, and identify the structural shocks $\eta_{i, t}$ as follows: $\eta_{i, t}=\mathbf{A}^{-1} \varepsilon_{i, t}$, where $\mathbf{A}$ is the lower triangular Cholesky factor of the residual variance-covariance matrix. 
It is common in the monetary transmission literature to order output and prices before the policy rate for two reasons: first, output growth and inflation are assumed to react only with one lag to a monetary policy shock; second, contemporaneous innovations which are common to output growth and the policy rate or inflation and the policy rate are not recorded as monetary policy innovations. Given the key role of credit intermediation during the recent crisis, the policy-makers gave importance to the results of the BLS in their policy decisions. Therefore, we have ordered them before the policy rate with the notion that the policy-makers can respond immediately after the release of the BLS results. As pointed out by Ciccarelli (2010), this identification of the monetary policy shock takes into account the forward looking character of the survey. All in all, the variables are ordered as follows: Real GDP growth, GDP deflator inflation, BLS demand factor, BLS supply factor, lending rate to NFCs-3-month OIS, 3-month OIS, loan growth to NFCs. However, the results are qualitatively similar whether the BLS supply factor is ordered last or first.

The impulse response functions of the credit supply shock are presented in Figure 3. The results suggests that real GDP declines for about 3 years with a loss amounting to 0.6 percentage points at the peak if the panel is estimated using 8 countries and 0.7 percentage points if the panel also included Greece, Ireland and Portugal. The impact on prices is also negative, but small ranging between 15 basis points after 2 years if the panel is formed by 8 countries and 25 basis points after 2 years and half if the panel included Greece, Ireland and Portugal. All in all, an unanticipated credit tightening has a temporary negative impact on output and prices, with responses that are generally more persistent when the panel included also Greece, Ireland and Portugal.

$$
\text { [insert Figure } 3 \text { here] }
$$

Regarding all other variables related to credit intermediation, the credit supply shock shifts on impact the BLS answer on credit standards. The tightening of bank lending policy leads to higher bank lending rate spreads and lower outstanding amount of loans. Such adverse bank lending channel effects imply a contraction of real GDP and lower inflation.

More specifically, the following features of the credit supply transmission mechanism should be emphasized. First, the maximum effect of output is reached after 5 quarters reverting back to baseline after 14 quarters while the impact on loans peaks after 10 quarters and is more persistent. The obtained impulse response functions are qualitatively very similar to Peersman (2011). The macroeconomic impact would be milder if the BLS supply factor would be ordered last, but stronger if it would be 
ordered first. The lagged impact of credit standards on bank loans is also confirmed using panel fixed effects models with loans to either NFCs or households regressed on credit standards. For instance Hempell and Kok Sørensen (2010) find a significant impact of credit supply factors on bank lending with a lagged effect of around three quarters on actual reported net lending figures. Credit supply factors take some time to affect loan dynamics while the impact on economic activity materialize more rapidly. This feature vindicates the use of the forward looking survey information in order identify credit supply shocks.

Second, the relative magnitude of output and loan response shows that after credit supply disturbances the peak effect on loans is much stronger than on GDP. The maximum impact on GDP is around 0.6 percentage points compared with 2 percentage points on loans. This result differs from Peersman (2011), but it is consistent with the estimated multipliers from the reduced-form analysis of Cappiello, et al. (2010) which found that a one percentage point shock to loan supply would give rise to a negative long-run impact on real GDP growth of around $0.3 \%$. The dynamic stochastic general equilibrium literature of models with financial frictions also presents qualitatively similar multipliers (see for example Christiano et al., 2010; Darracq et al., 2011).

Finally, the lending rate spreads reacts relatively little compared with the contraction in GDP and loans. Such a mild response indicates that the identification of the credit supply shocks through the BLS answers on credit standards is likely to gear the transmission towards quantitative bank lending channels related to non-price terms and conditions. Here again, the benefits of relying on BLS information to identify credit supply shocks are clear.

\subsubsection{Identification by sign restrictions}

Identification in sign-identified models requires that each identified shock is associated with a unique sign pattern. We employ the approach of Uhlig (2005), but adopt the algorithm of Rubio-Ramirez, Waggoner, and Zha (2010), as the latter is more efficient in dealing with sign restrictions on impulse responses to a number of structural shocks.

If several structural shocks must be identified, Uhlig's algorithm searches for the orthogonal matrix column by column recursively. During this search, the orthogonal matrix may not be found for some draws, either from the bootstrap procedure or from the posterior distribution. Conversely, Rubio-Ramirez, Waggoner, and Zha' algorithm keep all the posterior draws in practice and the orthogonal matrix is simply a draw from the uniform (or Haar) distribution with only a single operation of the 
QR decomposition. ${ }^{3}$ These differences make Rubio-Ramirez, Waggoner, and Zha' algorithm more efficient when several shocks are to be identified.

The basic steps are the following:

(1) Draw a set of unrestricted parameters $\mathbf{A}$ from the posterior distribution (inverse Wishard for the covariance matrix $\sum$ and Normal for the reduced form parameters $\mathbf{B})$.

(2) For each draw of $\mathbf{A}$, compute $\sum$ and $\mathbf{B}$.

(3) Compute the eigenvectors of $\sum$ normalized.

(4) Draw N independent standard normal vectors of length $\mathrm{N}$ from a uniform distribution.

(5) Generate impulse responses.

(6) If these impulse responses satisfy the sign restrictions, keep the draw; otherwise, repeat all the steps.

The Bayesian approach requires forming a prior for the reduced-form VAR. We employ $\sum$ and $\mathbf{B}$ estimated using the Arellano-Bond GMM estimator.

Following Peersman (2012), we identify three main shocks: a credit supply shock, a monetary policy shock and an aggregate demand shock. However, while Peersman (2012) imposes a sign restriction on loan volumes, we identify the shocks using the BLS demand and supply factors. Therefore, the short run responses to a contractionary shock take the following sign:

\begin{tabular}{lccc}
\hline \hline & Credit supply & Monetary policy & Aggregate Demand \\
\hline GDP Growth & - & - & - \\
Inflation & - & - & - \\
Credit demand factor & & & - \\
Credit supply factor & + & & - \\
Cost of lending & + & + & - \\
Interest rate & - & + & \\
Loan growth & & & \\
\hline \hline
\end{tabular}

The impulse response functions of the credit supply shock are presented in Figure 4. Beyond the scaling of the shock, the results suggests a high degree of similarities with respect to the previous shock identification. First, the dynamic responses of output and loan do comfort previous findings, regarding the delayed response of

\footnotetext{
${ }^{3}$ In linear algebra, a QR decomposition (also called a QR factorization) of a matrix is a decomposition of a matrix $\mathrm{A}$ into a product $\mathrm{A}=\mathrm{QR}$ of an orthogonal matrix $\mathrm{Q}$ and an upper triangular matrix R.
} 
loans or peak GDP effects after 5 to 6 quarters. Second, the identification with sign restriction also confirms the stronger impact on loans than on GDP of credit supply disturbances. From peak to peak, loans react by 3.5 times more than GDP, precisely like in the recursive identification scheme. Third, the inflationary effects of the credit supply shock is very close to the one obtained previously for a given output effect, albeit somewhat more persistent.

\section{[insert Figure 4 here]}

At the same time, some striking differences should be noticed. It appears that the sign restriction scheme delivers on impact a milder response of the BLS answer on credit standards but stronger responses of BLS answers on loan demand and loan rate spreads. In comparison, the recursive identification scheme may therefore impose some strong assumptions on the instantaneous response of the BLS supply variable. The next section, which analyses the historical decomposition of the shock, will also assess whether these differences significantly affected the model-based assessment on the role of credit supply shocks in the euro area business cycle.

\subsection{Credit supply factors during the financial crisis}

We now turn to the economic importance of credit supply disturbances in the euro area business cycle. The results from the recursive identification scheme are analyzed first, followed by the comparison with the sign restriction outcomes.

Four main periods can be identified over the last decade: the period before the financial crisis started up to June 2007, when credit standards were eased; the period up to March 2009, when the global crisis unfolded and credit standards were tightened; the short period up to December 2009, when credit standards saw some easing; and the subsequent period up to December 2011, when the re-emergence of credit supply tensions were strongly contributing to higher net tightening of credit standards (see Figure 5).

\section{[insert Figure 5 here]}

Clearly, the credit supply shocks are found to be important drivers of the BLS answer on credit standards. However, in some periods, the credit supply disturbances were not fully explaining the developments in this BLS variable. In 2010, notably, the overall answers of banks were pointing to more neutral stance on bank lending policies, despite the credit supply shock re-emerged very strongly. This demonstrates the need to treat the BLS variables as endogenous in the panel-VAR system in order 
to account for the dynamic interactions with other factors in order to better measure credit supply effects.

Starting with the pre-crisis period, credit supply factors supported the economic recovery from 2005 to 2007. The positive contribution to annual GDP growth peaked at around 1.5 percentage points in 2005, receding thereafter. The associated effects on price dynamics reached 0.3 percentage points of annual GDP deflator inflation. Turning to credit variables, up to 3 percentage points of annual loan growth was explained by credit supply disturbances in 2006 and 2007 while lending rate spreads were compressed by almost 30 basis points (see Figure 6).

[insert Figure 6 here]

Through the 2008-09 episodes, the positive contribution of credit supply factors to GDP growth was rapidly reabsorbed and turned largely negative. At the trough, in the beginning of 2009 , the contribution reached -1.8 percentage points getting back to a small positive number in early 2010. While sizeable, the credit supply effects identified by the model still fall short of explaining the overall contraction of GDP over the period. In 2008-2009, the credit supply factors also implied temporary disinflationary pressures, by -0.3 percentage points at the maximum in 2009. Over the same period, up to -1.5 percentage points of annual loan growth was constrained due to credit supply shocks which also fuelled lending rate spreads by around 20 basis points. Between end-2009 and early-2010, all those effects receded and became residual.

But the resurrection of financial tensions in 2010 and even more so since mid2011, led to some turn around in the contribution of the credit supply shocks to the variables of Figure 6 . The renewed adverse credit supply shocks have been weighting on annual GDP growth by -0.5 percentage points in 2011 while containing inflation by less than -0.2 percentage points. The drag on loan dynamics reached 1.5 percentage points and the contribution to lending rate spreads increased back to 20 basis points.

Turning now to the in-sample structural decomposition implied by the sign restriction identification scheme, the results are presented and systematically compared with the previous ones in Figure 5 for the BLS variables and in Figure 7 for goods and credit markets variables. One striking similarity concerns the historical decomposition of GDP, loans and to a lesser extent inflation. As suggested by the comparison of impulse response functions, the two identification schemes attribute almost the same impact of credit supply tensions on activity and lending through the crisis, whereas the contribution to inflation dynamics appears broadly similar but somewhat more pronounced with sign restrictions. On the BLS variables, the results are qualitatively 
comparable but on credit standards in particular, the contribution of credit supply shocks identified with sign restrictions turns out to be more moderate and less volatile. Finally, the historical decompositions of lending rate spreads display more pronounced differences with the sign restrictions attributing stronger credit supply effects. These differences on BLS credit standards and lending spread variables correspond to the ones illustrated when comparing the impulse response functions.

\section{[insert Figure 7 here]}

Overall, the two identification schemes implemented in this paper deliver comparable macroeconomic propagation and similar explanatory power on euro area economic developments through the crisis. Such similarities are worth emphasizing given the strong conceptual and technical differences between the two identification strategies.

\section{The macroeconomic impact of the 3-year LTROs through bank credit supply}

\subsection{Why focusing on the bank lending channel?}

As mentioned earlier, the empirical analysis on the impact of the 3-year LTROs assumes that the main transmission channel of this non-standard monetary policy measure works through the mitigation of liquidity and funding risks in the euro area banking system which ultimately contributes to relax bank lending standards and supports the financing of the economy at large.

Within our panel-VAR framework, the effects of the 3-year LTROs on the euro area macroeconomy will therefore be inferred using the privileged information on bank lending practices from the BLS and the associated identification procedure for credit supply shock presented in the previous sections. This strategy contrasts with other approaches found in the recent literature addressing the macroeconomic effects of unconventional monetary policy (Giannone, et al., 2012; Gambacorta, et al., 2012).

At the same time, one must acknowledge that other channels may potentially be ignored by our identification strategy. For example, non-standard measures may also be perceived as commitment devices from the monetary authority on its readiness to act and ability to deliver on its mandate, when the room for further accommodation through standard monetary policy instrument is narrow. Such expectational channels are absent from the analysis presented in this paper; thereby we might neglect potentially powerful transmission mechanisms of the 3-year LTROs. 
Additional transmission channels, which go beyond or by-pass the provision of loans by the banking system, are connected to the effects of the 3-year LTROs on macroeconomic risk distribution and on the price of risk. At the end of this section, we conduct an additional scenario to make the point.

\subsection{Interpreting the 3-year LTROs as the unexpected credit supply shock in the first half of 2012}

In this section, the evaluation of the 3-year LTRO impact on the euro area macroeconomy will be conducted along two simulation exercises. First, the effect of the non-standard measure is assumed to be exclusively attributed to the credit supply shocks explaining the forecast errors on the BLS answers included in the panel-VAR and released in the April 2012 survey round. Second, we make use of an unpublished ad hoc questionnaire of the BLS collected between 9 and 15 February 2012, which provides the bank answers on the effect of the 3-year LTROs on credit standards. Both counterfactual exercises identify the macroeconomic effects of this non-standard monetary policy measure in two ways: the non-standard measure constitutes a favorable credit supply shocks and the dating of the event corresponds to developments in the BLS answers in the first two quarters of 2012.

First the results will be derived with the recursive identification scheme. The 3-year LTROs are assumed to have contributed through credit supply shocks to the unexpected changes of the BLS answers on loan demand and credit standards in 2012Q1 as well as in 2012Q2 based on respondents expectations formulated in the April 2012 survey round. In practice, we run the one-sided Kalman filter for 2012Q1 and 2012Q2 using the euro area VAR compatible with the panel-VAR estimation, and treating as observed variables the BLS answers on the net demand for loans and the net percentage changes of credit standards to enterprises. The associated credit supply shocks for the two consecutive quarters are presented in the two first lines of Figure 8 for the versions of model based on 8 or 11 countries respectively. It turns out that for the first quarter of 2012, a favorable credit supply shock is extracted and amounts to around 20 percentage points. This shock is fully explaining the onequarter-ahead forecast error for 2012Q1 corresponding to the unexpected decline in the net tightening of credit standards. For the second quarter of 2012, the smoothed credit supply shock is almost negligible.

[insert Figure 8 here]

One may argue that this favorable credit supply shock in 2012Q1 could be related 
to other factors than the 3-year LTROs. In order to corroborate our interpretation, we relate the bank-level distribution of answers in the BLS to the actual bidding behavior of the respective banks in the two 3-year LTROs. We find that the net tightening of credit standards for loans to enterprises was much higher in 2011Q4 and decline more strongly in 2012Q1 for the group of banks which participated in at least one of the two 3-year LTROs than for the non-bidding banks. Actually the net tightening of credit standards for the non-bidding banks even increased from 2011Q4 to 2012Q1. Consequently, the banks which did use the funds from the 3-year LTROs have been the ones contributing to the lower than expected outcome for the BLS answers on credit standards included in the panel-VAR. This justifies the interpretation of the favorable credit supply shock in 2012Q1 as driven by the 3-year LTROs.

The macroeconomic impact of the 3-year LTROs could then be assessed by simulating the dynamic response of variables in the panel-VAR to the two credit supply shocks for 2012Q1 and 2012Q2. Observing all variables up until 2011Q4, this simulation is equivalent to the difference between the contribution of credit supply shocks identified in the first half of 2012 to the h-step ahead forecast and the unconditional h-step ahead forecast. The first line of panel A in Figure 9 presents the results of this exercise using as before the model 3 with either 8 or 11 countries. The response of euro area real GDP in level displays a hump-shaped pattern reaching a peak by mid-2013 at 0.7-0.8 percentage points depending on the version of the model. By end-2014, real GDP remains 0.2-0.4 percentage points above baseline. The effects on inflation materialize with some lag with the annual inflation rate increasing by $0.15-0.25$ percentage points at the peak in the beginning of 2014. Turning to credit variables, the outstanding amount of bank loans to non-financial corporations responds very gradually with maximum effects recorded in the second half of 2014, almost two years later than for GDP, at around 2-2.5 percentage points above baseline. At the same time, the lending rate spread declines by 15-20 basis points in the first quarters, reverting back to zero by mid-2014. As mentioned previously, the moderate narrowing of lending rate spreads compared with the improvement of economic activity and loan provision is consistent with the identification of the credit supply shocks through the BLS answers on credit standards. A relaxation of credit standards in the BLS is indeed more related to a quantitative easing of loan supply.

[insert Figure 9 here]

We then compare the results of this counterfactual exercise with the ones obtained using the sign restriction identification scheme. Favorable credit supply shocks in 2012Q1 and 2012Q2 are identified with sign restrictions but appear milder (see panel C 
of Figure 8). This also translates into comparable but less pronounced macroeconomic effects of the counterfactual experiment (see panel A of Figure 9). The maximum impact reaches 0.5 percentage points for GDP and 1.7 percentage points for loans while the lending rate spread narrows down by 10 basis points. The effect on inflation is within the range of results found previously. This alternative identification scheme is therefore comforting the broad assessment of the macroeconomic benefits associated with the 3-year LTROs, but points to somewhat lower quantitative estimates.

The delayed response of loans compared to economic activity is a constant feature of our simulations. Indeed, the transmission of such liquidity injections is complex, as it involves the assessment of the whole balance sheet of banks and the effects of the current adjustment of bank capital on the funds available for lending. Moreover, even if banks are willing to increase the supply of loans, the granting of such loans requires time due to the technical steps involved in the process. Therefore, one should not expect a close short-term relationship between the amounts of net liquidity granted to banks of specific countries and the flow of loans to households and NFCs granted by the banks in those countries.

Given the similar results obtained using the two identification strategies, additional counterfactual simulations will only be carried out with the recursive identification scheme from now onwards. ${ }^{4}$

\subsection{Making use of a special ad hoc BLS on the effect of the 3-year LTROs}

A special ad hoc BLS, aimed at assessing the impact on euro area banks of the 3-year LTROs, was conducted in mid-February 2012 for internal ECB purposes and is unpublished. The survey aimed at assessing the banks' reasons, the level of participation, the use of the funds collected and the impact on credit standards.

The simulation exercise based on the ad hoc BLS makes use of the euro area aggregated bank replies on whether the recourse to the 3-year LTORs implied some relaxation of credit standards for loans to enterprises over the next six months. The average net loosening of credit standards for 2012Q1 and 2012Q2 is then directly interpreted as credit supply shocks in the panel-VAR.

The difference between the contribution of credit supply shocks to the h-step ahead forecast and the unconditional h-step ahead forecast is reported in panel B of Figure 9, using the two versions of the model based on 8 and 11 countries. The results are very

\footnotetext{
${ }^{4}$ Results with sign restrictions, which are not reported thereafter, are available from the authors upon request.
} 
similar across the two specifications with some exception for inflation. The simulation leads to higher real GDP over the next three years. The peak effect is reached in mid2013 at 0.6 percentage points declining thereafter towards 0.2 percentage points in 2014Q4. Inflation edges up by $0.15-0.20$ percentage points in 2014. The outstanding amount of bank loans gradually increases by 2 percentage points over the next three years, while lending rates decline by 14 basis points by end-2012.

The results with the ad-hoc survey turn out to be strikingly similar compared with the results obtained using the April BLS survey, where credit supply shocks are fully endogenously determined. The expansionary effects are somewhat smaller when using the ad-hoc BLS survey and the model with 11 countries, but almost the same when the panel excludes Greece, Ireland and Portugal. These converging outcomes reinforce the plausibility of our interpretation that the unexpected favorable credit supply shock related to the release of the April 2012 BLS was due to the 3-year LTROs.

\subsection{Focusing the credit supply channels on liquidity risk and access to market funding}

An additional simulation exercise aims at identifying the credit supply channel using some specific supply-side determinants of bank lending policy, such as banks' liquidity management, access to market funding and capital positions, information included in the BLS survey.

We replace in the panel-VAR the BLS answers on credit standards by the aggregation of these three specific supply factors. In doing so, the identified credit supply shocks become more strictly related to banks' funding constraints, which the ECB policy aimed at relaxing.

Based on this new BLS variable, the panel-VAR is re-estimated using samples of 8 or 11 countries, the credit supply shock is identified as before and the simulation is reproduced as an unexpected credit supply shock in the first half of 2012 (see panel $\mathrm{C}$ of Figure 9). Compared with the first exercise displayed in panel $\mathrm{A}$, the effects of the 3-year LTROs have broadly the same dynamic features across variables, but are stronger.

Focusing on the model version with 8 countries, the peak effect on the GDP reaches 1 percentage points by mid-2013, 0.3 percentage points higher than in the first exercise. At the end of 2014 however the effect is similar. The impact on inflation is also more elevated by 0.15 percentage points on average over 2013 and 2014 . Credit expansion is more pronounced by 1 percentage points while the lending rate spread 
declines by 15 basis points more. The differences with the results of the first exercise are even more pronounced and more persistent regarding GDP and inflation if the model is estimated on 11 countries.

All in all, focusing the credit supply indicators on the most acute sources of bank vulnerabilities during the financial crisis and accounting for the historical experience of the weakest countries increase significantly our measurement of the effectiveness of ECB's non-standard measures.

\subsection{Accounting for the 3-year LTROs impact on financial market uncertainty and risk aversion}

As mentioned at the start of the section, the evaluation of ECB's non-standard measures in this paper focuses exclusively on the bank lending transmission channel for the main reason that those measures were precisely predicated against the emergence of exceptional tensions within the euro area banking systems. At the same time, the econometric analysis along this assumption may potentially neglect powerful mechanisms through which the 3-year LTROs can affect the euro area economy. One of them is certainly related to the distribution of economic risks and financial market sentiment towards risk taking.

As a robustness analysis, we therefore incorporate in the panel-VAR a financial variable likely to capture those factors. A popular indicator used in the macrofinancial empirical literature is the VIX, an index of stock market option-implied volatility. Bekaert et al (2010) show that the VIX reflects both economic uncertainty as well as risk aversion of investors and that the changes in risk aversion tend to be sensitive to monetary policy actions and to have relatively strong impact on the business cycle. Here, we will not investigate the respective role of risk aversion and uncertainty in the context of the 3-year LTROs which would go beyond the scope of this paper. Instead, we only investigate (as kindly provided by the authors) how both components of the VIX evolved in 2011Q4-2012Q1 and found that risk aversion, uncertainty and the overall index declined broadly to the same extent during this period. Consequently, whether the effects of 3-year LTROs work through risk aversion or uncertainty may somehow be not so relevant when relying on the overall VIX indicator.

Using the VIX-augmented panel-VAR with 8 countries, we revisited the two previous exercises. First, the simulation of the credit supply shock based on the ad hoc BLS questionnaire (see section 4.3) enables to compare the transmission of the shock in the two models and to assess whether adding the financial risk variable would 
strongly mute the credit supply channels. As displayed in the Panel A of Figure 10, it turns out that the propagation of the credit supply shock and therefore the quantification of the macroeconomic impact of the 3-year LTROs remains broadly similar to the previous ones. With comparable dynamic properties, the magnitude of the effects is nonetheless smaller: for example, the pick effect on GDP reaches 0.5 percentage points with the VIX-augmented model which is 0.1 percentage points lower than with the benchmark model. Therefore, controlling for the financial factor mitigates slightly the quantification but leaves the broad assessment on the non-standard measures unchanged.

The second simulation reproduces the exercise of section 4.2 , which attributes the impact of the 3-year LTROs to the unexpected credit supply shocks in 2011Q1 and 2012Q2 due to the forecast errors on the BLS answers. With the VIX-augmented model however, we include the VIX in the set of observed variables and therefore also control for the forecast errors on the VIX when extracting the structural shocks. Moreover, in order to allow for a potential effect of the 3-year LTROs on the economy beyond the bank lending channel, we consider both the unexpected financial and credit supply shocks in the simulation. The financial shock is obtained recursively using Cholesky and ordering the VIX last. The outcome is presented in the panel B of Figure 10 together with the benchmark results of Panel A of Figure 9. The effects are strikingly similar for both GDP and bank loans. On inflation however, the impact with the new model is stronger with inflation reaching 0.25 percentage points at the peak, compared with 0.15 percentage points in the benchmark case. The response of lending rate spreads is more volatile but delivers broadly the same average quantitative effect.

\section{Insert Figure 10 here]}

Overall, the robustness analysis of this section shows that the quantitative assessment would not significantly change by controlling for financial variables in the panel-VAR system or broadening the transmission channel of the 3-year LTROs to risk aversion and uncertainty.

\section{Conclusions}

The aim of the paper is to assess the macroeconomic impact of the 3-year LTROs conducted by the ECB in December 2011 and February 2012. The main transmission channel of this non-standard monetary policy measure works through the mitigation 
of liquidity and funding risks in the euro area banking system, which ultimately contributes to relax bank lending standards and supports the financing of the economy at large.

We argue that we can identify this non-standard measure by focusing on the bank lending channel, thereby using information from the Bank Lending Survey (BLS) covering the largest banks of each euro area country. Within a panel-VAR framework, the effects of the 3-year LTROs on the euro area macroeconomy are therefore inferred using the privileged information on bank lending practices from the BLS and the associated identification procedure for credit supply shocks.

The evaluation of the 3-year LTROs impact on the euro area macroeconomy is first inferred through the credit supply shocks identified recursively as well as with sign restriction methods based on the BLS answers in the April 2012 survey round and second, using an unpublished ad hoc questionnaire of the BLS collected between the 9th and the 15th of February 2012, which provides the bank answers on the effect of the 3-year LTROs on credit standards. All simulation exercises turn out to deliver very similar quantitative effects.

The results suggest that the 3-year LTROs are expansionary over the short to the medium term and associated with increases in GDP, loan volume to non-financial corporations and a compression of lending rate spreads. The economic support of the non-standard measure is only gradually reflected in loan dynamics while the benefits on output materialize earlier. Moreover, given the relatively muted response of spreads compared to loans, the LTROs seems to act more on the economy through quantitative credit easing than lower cost of financing.

The success of the 3-year LTROs in reducing funding risk in the banking sector can also be demonstrated by the developments of the inter-bank risk measured by the 3-month EURIBOS-OIS spread in the first half of 2012. Despite the renewed tensions in the euro area sovereign debt market in the second quarter of 2012 owing to several factors such as the solvency of some banks in Spain, negative macroeconomic releases unexpected by markets, market perception of higher political risk (political election in Greece, referendum in Ireland on the fiscal compact, debate about the role of ESFS/ESM as firewall, ${ }^{5}$ discussions on banking union and mutualisation of financial

\footnotetext{
${ }^{5}$ The European Financial Stability Facility (EFSF) is a special purpose vehicle financed by members of the euro area to address the European sovereign-debt crisis. The European Stability Mechanism (ESM) launched on 8 October 2012 is designed to provide financing to distressed euro area members so long as they are committed to strict fiscal and structural reforms that aim to put economies that have lost investor trust back on track.
} 
risk in the euro area), this measure of interbank credit risk declined from 100 basis points on 8 December 2011 to 40 basis points at the end of March 2012 and fluctuated around it since then until the speech on the convertibility risk by the ECB President Draghi on 26 July 20012 (see Figure 11). After the speech, the interbank credit risk continued its declining trend reaching 12 basis points on 26 November 2012; such low level was obtained on 8 August 2007, the day before the ECB had to cope with the first signal of dislocation of the money market.

This money market resilience is consistent with the fact that bank funding risks were effectively reduced by the ECB measures announced on 8 December 2011, because the 3-year LTROs provided a window of opportunity for banks to deleverage in a more orderly fashion and to increase their liquidity and capital buffers in a sustainable manner.

[insert Figure 11 here]

Overall, our paper brings an empirical contribution to the literature on the effectiveness of unconventional monetary policy at times of financial distress. The quantitative findings show that in the presence of acute tensions, exceptional central bank liquidity measures could help supporting the provision of bank lending to the economy and avoid an abrupt dry-up of credit supply. This assessment is consistent with the view that non-standard monetary policy measures like the one analyzed in this paper are complementary to interest rate decisions and are essentially predicated on the basis of emerging financial frictions in the credit intermediation sector.

\section{References}

[1] Anderson, T.W. and C. Hsiao (1981), "Estimation of dynamic models with error components", Journal of the American Statistical Association, 76: 589-606.

[2] Arellano, M. and S. Bond (1991), "Some tests of specification for panel data: Monte Carlo evidence and an application to employment equations", Review of Economic Studies, 58: 277-297.

[3] Bernanke, B.S., Reinhart, V.R. and B.P. Sack (2004), "Monetary policy alternatives at the zero bound: An empirical assessment", Federal Reserve Board Finance and Economics Discussion Series, n. 48.

[4] Bekaert, G., Hoerova, M. and M. Lo Duca (2010), "Risk, uncertainty and monetary policy", NBER Working Paper series, n. 16397. 
[5] Blundell, R. and S. Bond (1998), "Initial conditions and moment restrictions in dynamic panel data models", Journal of Econometrics, 87: 115-143.

[6] Breitung, J. (2000). "The local power of some unit root tests for panel data," in B. Baltagi (ed.), Advances in Econometrics, Vol. 15: Nonstationary Panels, Panel Cointegration, and Dynamic Panels, Amsterdam: JAI Press, p. 161-178.

[7] Cappiello, L., Kadareja, A., Kok Sørensen, C. and M. Protopapa (2010), "Do bank loans and credit standards have an effect on output? A panel approach for the euro area", ECB Working Paper Series, n. 1150.

[8] Cecioni, M., Ferrero, G. and A. Secchi (2011), "Unconventional monetary policy in thery and in practice", Banca d'Italia Occasional Papers, n. 102.

[9] Choi, I. (2001), "Unit root tests for panel data," Journal of International Money and Finance, 20: 249-272.

[10] Ciccarelli, M., Maddaloni, A. and J.-L. Peydró (2010), "Trusting the bankers: a new look at the credit channel of monetary policy", ECB Working Paper Series, n. 1228.

[11] Christiano, L., Motto, R. and M. Rostagno, "Financial factors in economic fluctuations," ECB Working Paper series, n. 1192.

[12] Darracq Pariès, M., Kok Sorensen, C. and D. Rodriguez Palenzuela (2011), "Macroeconomic propagation under different regulatory regimes: Evidence from an estimate DSGE model for the euro area", International Journal of Central Banking, December Issue: 49-113.

[13] Gambacorta, L., Hofmann, B. and G. Peersman (2012), "The effectiveness of unconventional monetary policy at the zero lower bound: A cross-country analysis", mimeo.

[14] Giannone, D., Lenza, M., Pill, H. and L. Reichlin (2012), "The ECB and the interbank market", Economic Journal, 122: F467-F486.

[15] Hadri, Kaddour (2000). "Testing for stationarity in heterogeneous panel data," Econometric Journal, 3: 148-161.

[16] Hempell, H.S. and C. Kok Sørensen (2010), "The impact of supply constraints on bank lending in the euro area - crisis induced crunching?", ECB Working Paper Series, n. 1262. 
[17] Holtz-Eakin, D., Newey, W. and H. S. Rosen (1988), "Estimating vector autoregressions with panel data", Econometrica, 56: 1371-1395.

[18] Im, K. S., M. H. Pesaran, and Y. Shin (2003). "Testing for unit roots in heterogeneous panels," Journal of Econometrics, 115: 53-74.

[19] Lenza, M., Pill, H. and L. Reichlin (2010), "Monetary policy in exceptional times", Economic Policy, 62: 295-339.

[20] Levin, A., C. F. Lin, and C. Chu (2002). "Unit root tests in panel data: Asymptotic and finite-sample properties," Journal of Econometrics, 108: 1-24.

[21] Maddala, G. S. and S. Wu (1999). "A comparative study of unit root tests with panel data and a new simple test," Oxford Bulletin of Economics and Statistics, 61: $631-52$.

[22] Nickell, S. (1981), "Biases in dynamic models with fixed effects", Econometrica, 49: $1417-1426$.

[23] Peersman, G. (2011), "Macroeconomic effects of unconventional monetary policy in the Euro area", CEPR Working Paper, n. 8348.

[24] Peersman, G. (2012), "Bank lending shocks and the euro area business cycle", mimeo.

[25] Rubio-Ramirez, J.F, Waggoner, D. and T. Zha (2010), "Structural Vector Autoregressions: Theory of identification and algorithms for inference", Review of Economic Studies, 77: 665-696.

[26] Sims, C. (1980), "Macroeconomics and reality", Econometrica, 48: 1-48.

[27] Uhlig, H. (2005), "What are the effects of monetary policy on output? Results from an agnostic identification procedure", Journal of Monetary Economics, 52: 381-419. 
Fig. 1. The ECB monetary policy stance

(Sample period: 2003Q1-2011Q4. \%, basis points.)

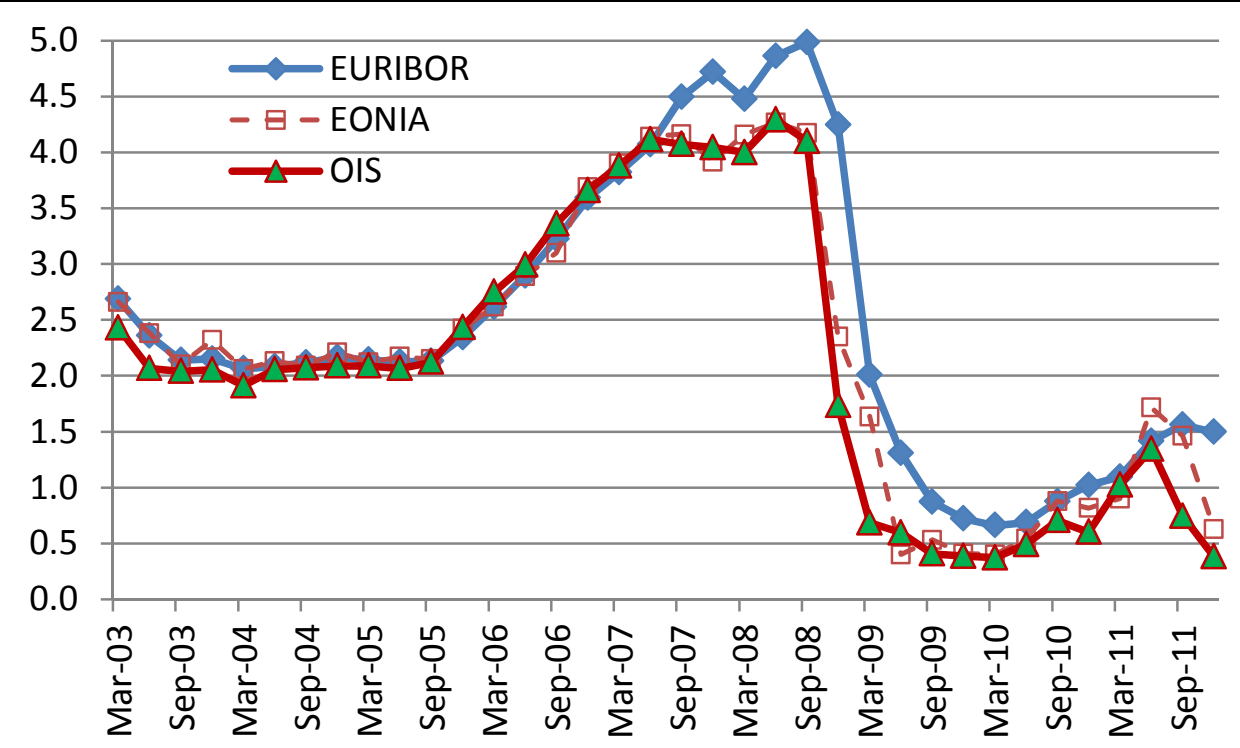

Source: Thomson Reuters. 
Fig. 2. Changes in credit standards applied to the approval of loans to enterprises and changes in demand for loans to enterprises in the euro area and selected euro area countries (net percentages of banks reporting a tightening standards - BLS supply factor-and an increase in loan demand - BLS demand factor. Sample period: 2003Q1-2012Q1)

Euro area

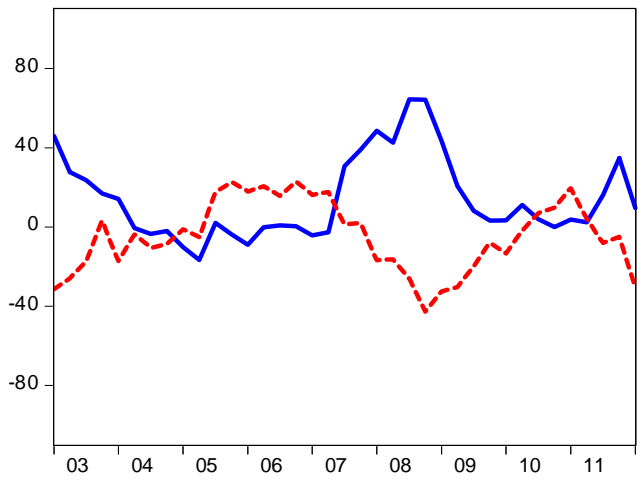

Italy

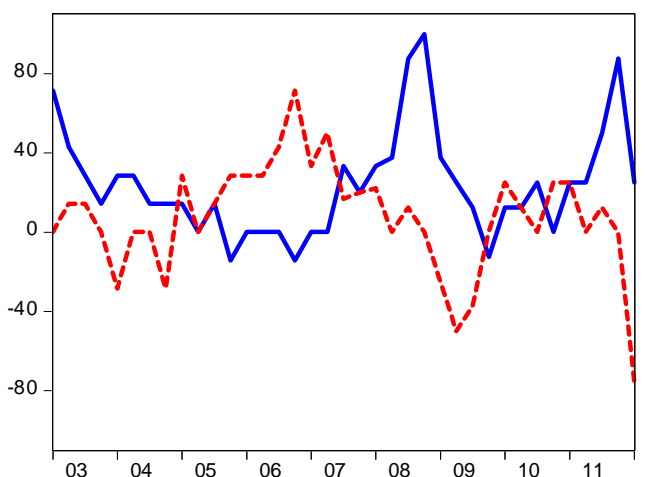

Netherlands

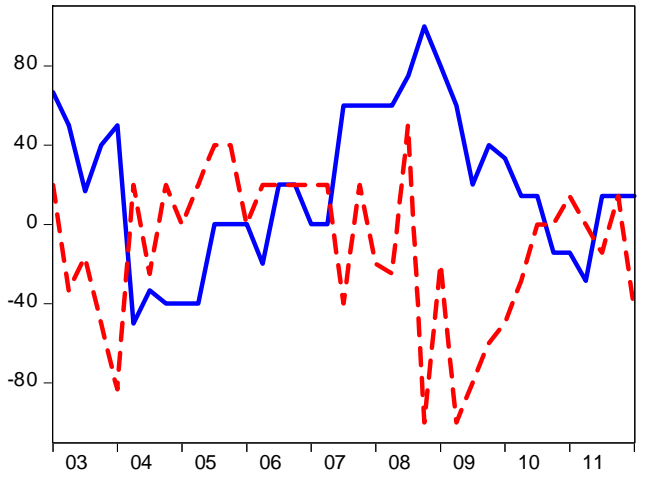

-BLS - credit supply factor (net percentage) - BLS - credit demand factor (net percentage)
Germany

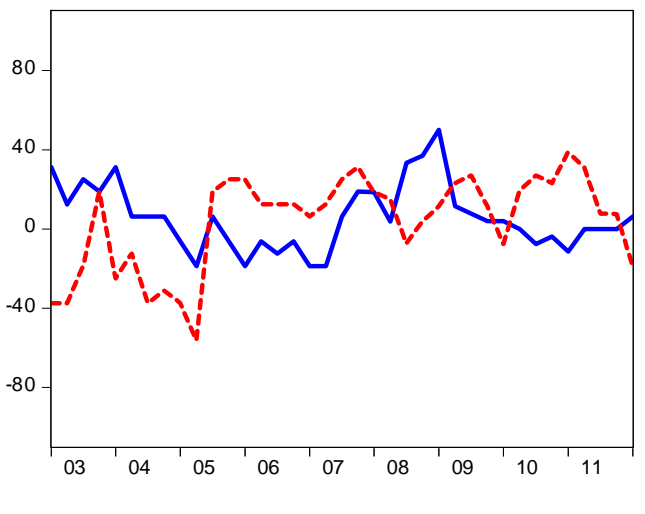

Spain

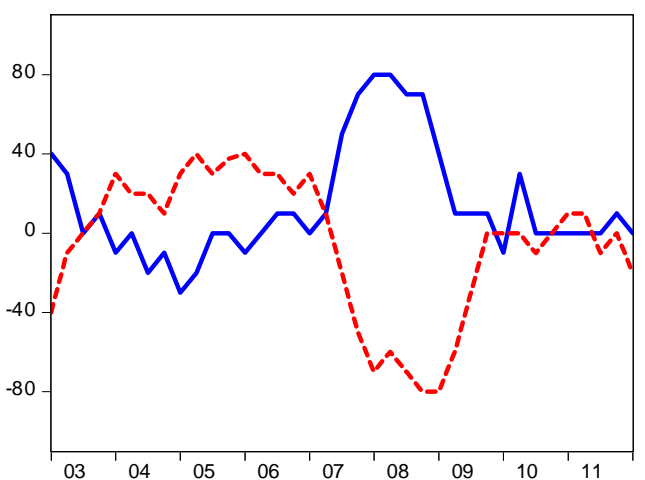

Portugal

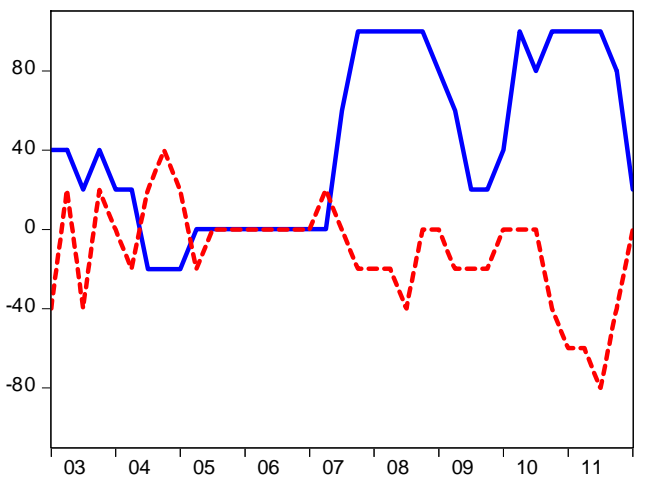

- BLS - credit supply factor (net percentage) - - BLS - credit demand factor (net percentage)

Source: $E C B$.

Notes: The net percentage for the questions on supply of loans refers to the difference between the sum of the percentages for "tightened considerably" and "tightened somewhat" and the sum of the percentages for "eased somewhat" and "eased considerably". The net percentages for the questions on demand for loans are defined as the difference between the sum of the percentages for "increased considerably" and "increased somewhat" and the sum of the percentages for "decreased somewhat" and "decreased considerably" 
Fig. 3. Impact of a credit supply shock on real GDP and GDP deflator

(Accumulated response to Cholesky one s.d. innovations \pm 2 S.E.)

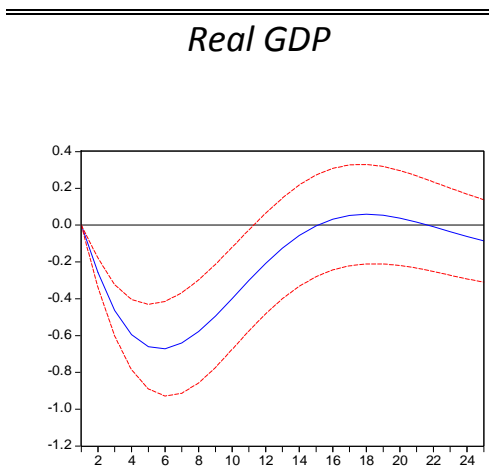

GDP Deflator

Monetary policy rate

Panel with 8 countries
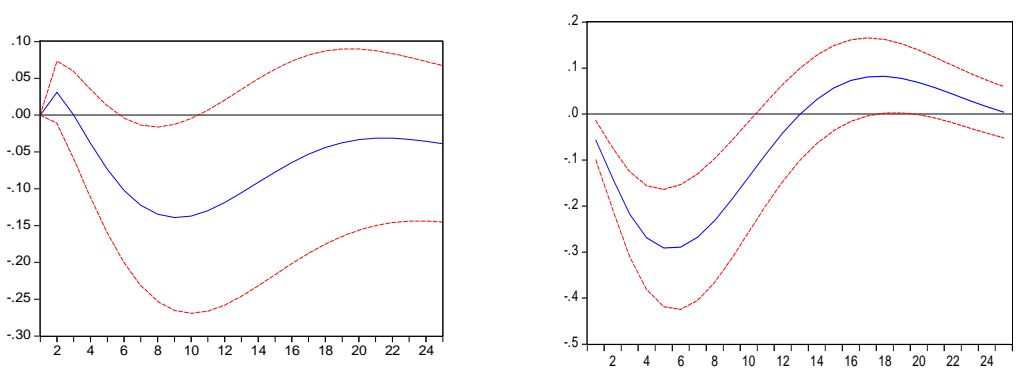

Panel with 11 countries
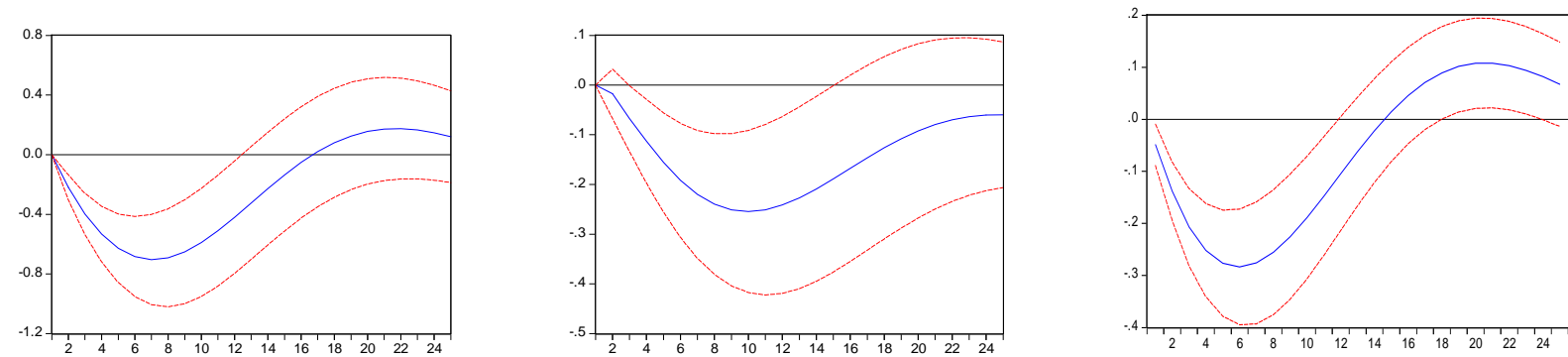

Panel with 8 countries

BLS demand factor
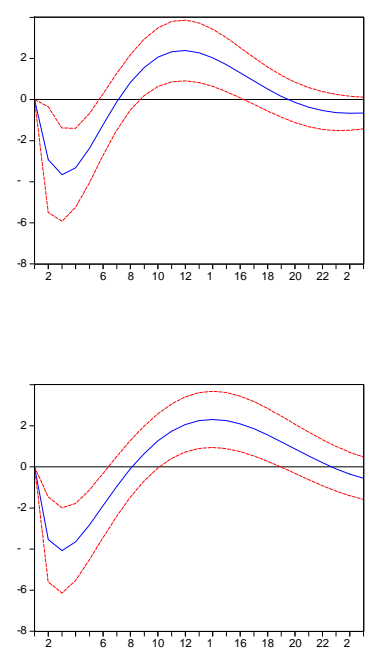

BLS supply factor

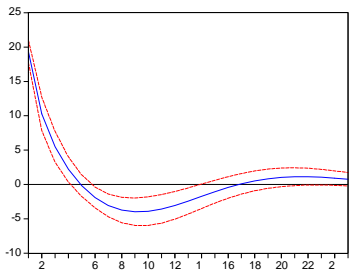

Lending rate spread

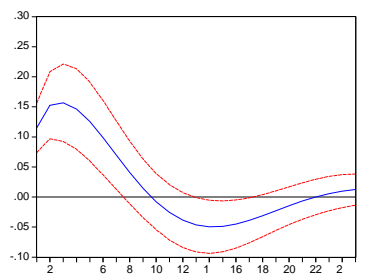

Loans to NFCS

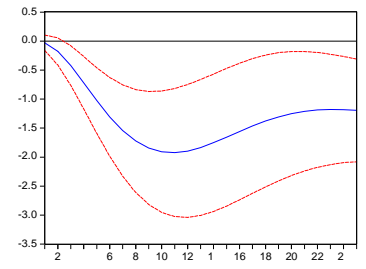

Panel with 11 countries
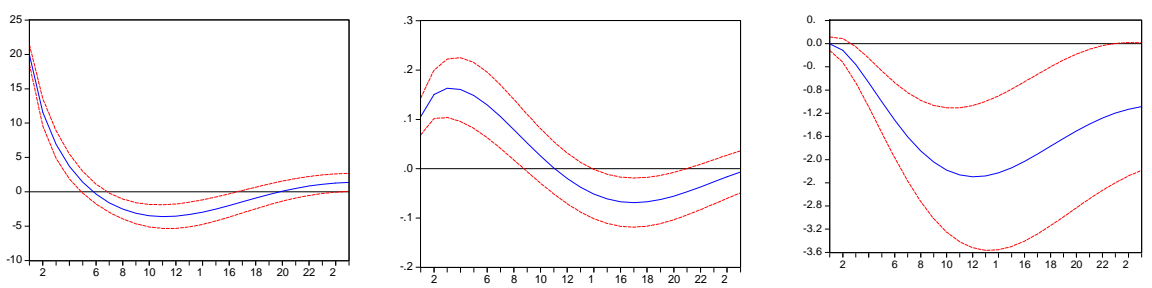

Notes: The model includes Real GDP growth, GDP deflator inflation, BLS demand factor, BLS supply factor, Lending rate to NFCs minus 3-month OIS, 3-month OIS, Loans to NFCs. The model is estimated over the 2003Q1-2011Q4 period. The credit supply shock is obtained using a standard Choleski-decomposition with the variables ordered as reported in this footnote. The underlying assumptions are that the BLS supply factor identifies credit supply and the shock has no contemporaneous impact on output, prices and BLS demand factors. The panel with 8 countries include: Austria, Belgium, Finland, France, Germany, Italy, Netherlands and Spain. The panel with 11 countries adds the adjustment programme countries: Greece, Ireland and Portugal. 
Fig. 4. Impact of credit supply shocks using sign restrictions

(response to one s.d. innovations, median of the responses along with the $16 \%$ and $84 \%$ percentiles)
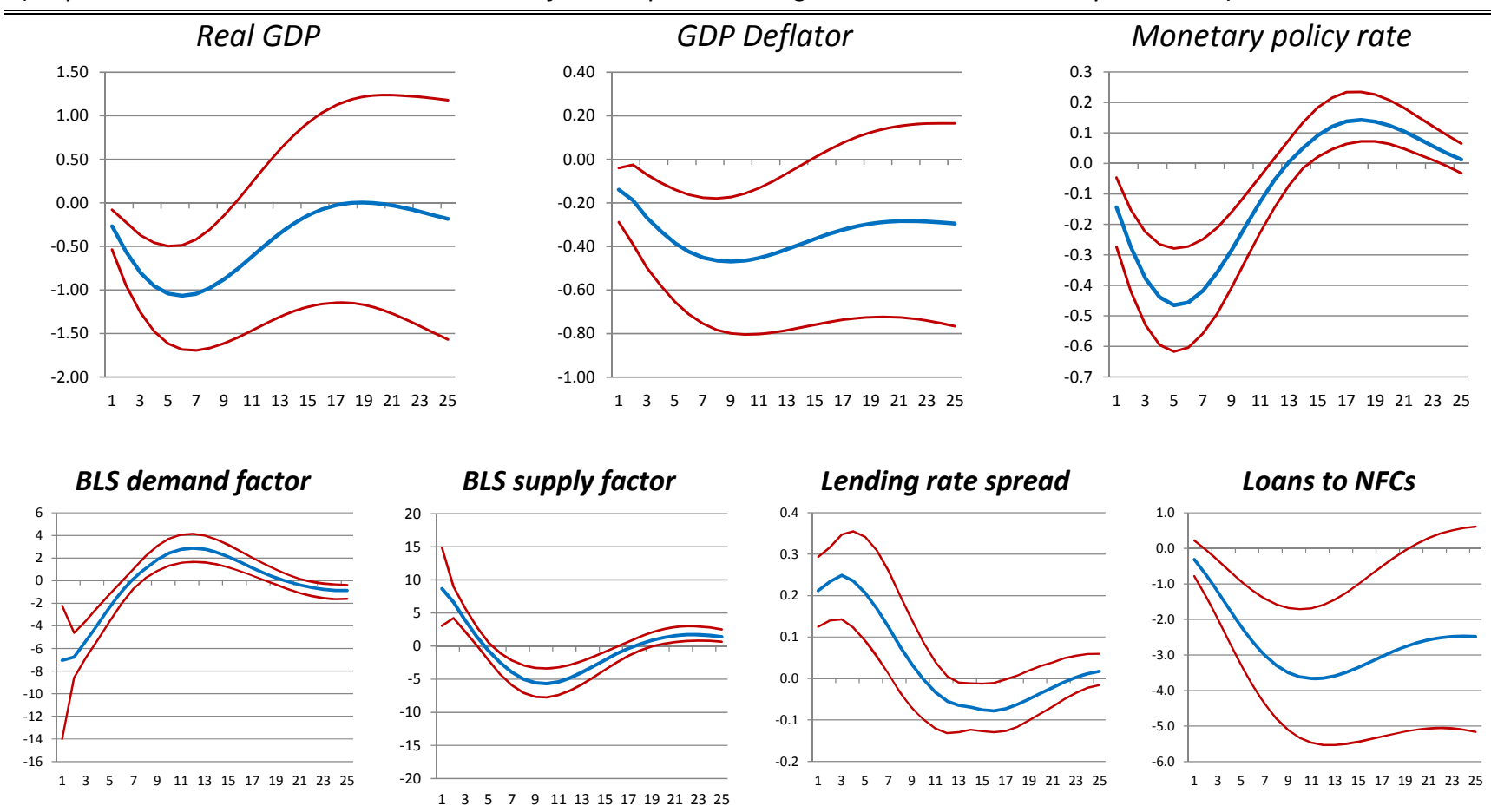

Notes: The VAR specification includes Real GDP growth, GDP deflator inflation, BLS demand factor, BLS supply factor, Lending rate to NFCS, 3-month OIS, and Loan growth to NFCs. The model is estimated over the 2003Q1-2011Q4 period. The credit supply shock is obtained using sign restrictions. The panel with 11 countries include: Austria, Belgium, Finland, France, Germany, Italy, Netherlands, Spain, Greece, Ireland and Portugal. 
Fig. 5. Historical decomposition of the credit supply shock on BLS credit supply and demand factors in the euro area (net percentages of banks reporting a tightening standards - BLS supply factor - and an increase in loan demand - BLS demand factor. Sample period: 2003Q1-2011Q4)

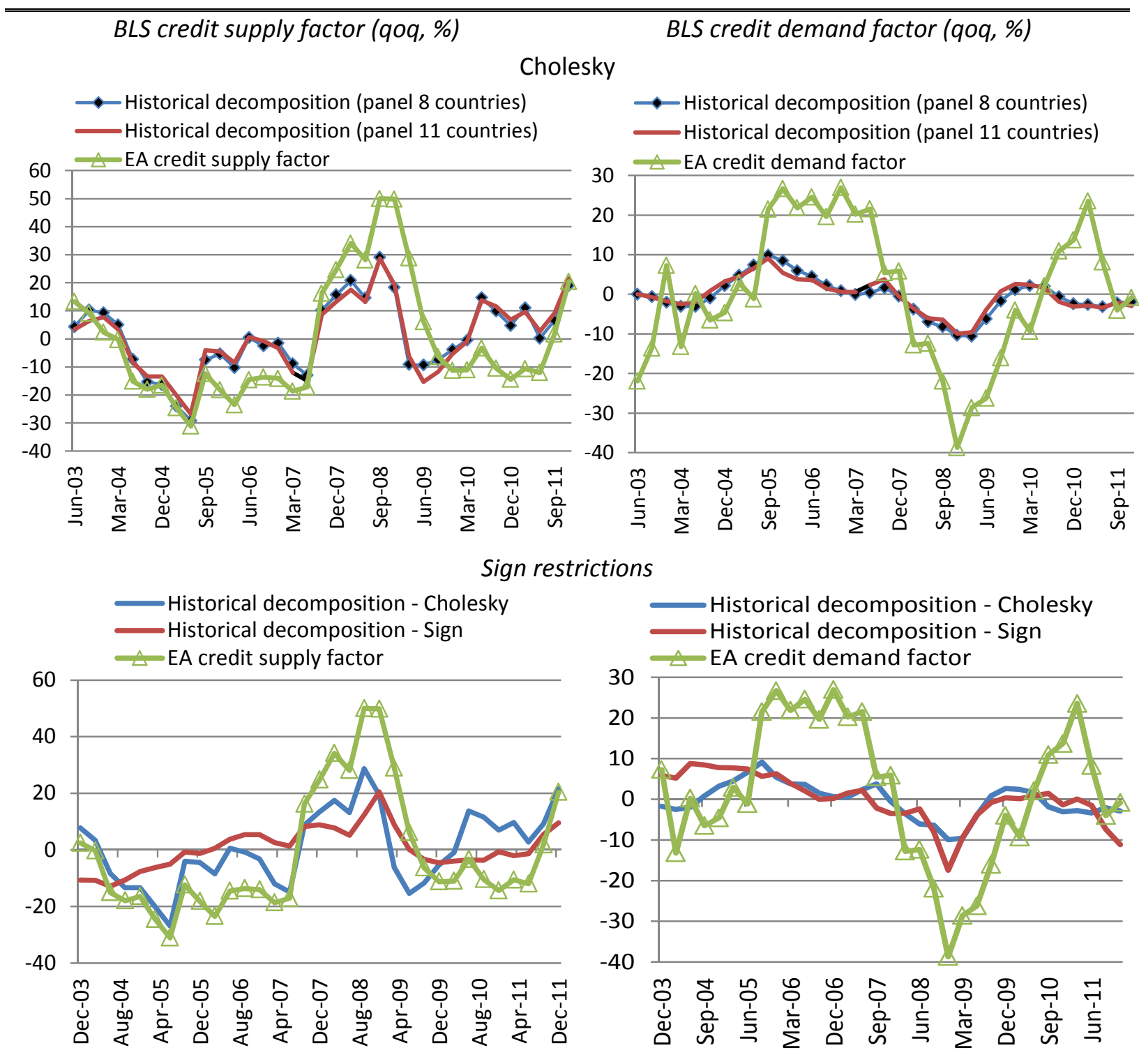

Notes: see Figures 4 and 5. 
Fig. 6. Historical decomposition of the credit supply shock on the euro area macroeconomy (Sample period: 2004Q1-2011Q4. Percent (\%) or percentage points (pp); year-on-year (yoy) or yearly average).

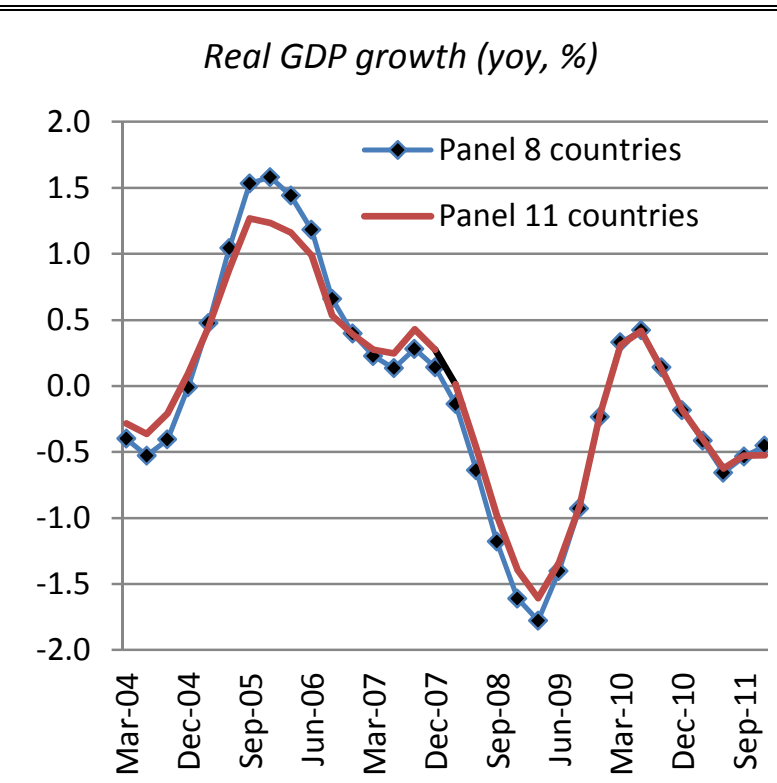

Loan growth to NFCs (yoy, \%)

GDP deflator inflation (yoy, \%)

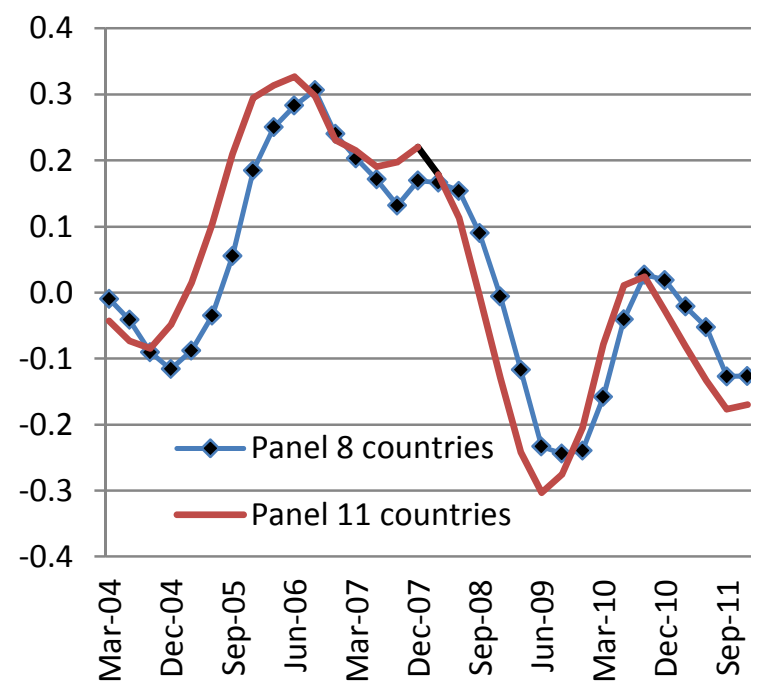

Lending spread to NFCs (yearly average, $p p$ )
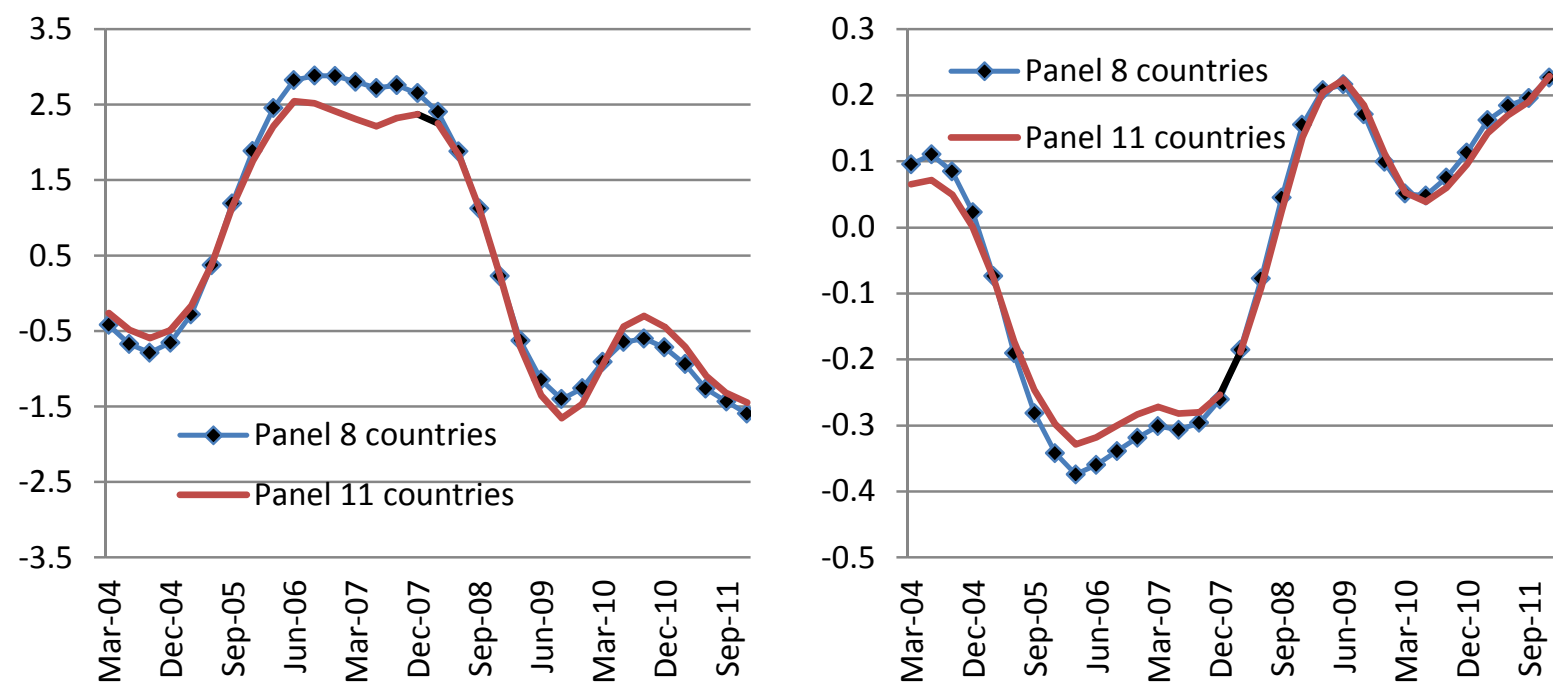

Notes: see Figure 4. 
Fig. 7. Historical decomposition of the credit supply shock on the euro area macroeconomy using sign restrictions

(Sample period: 2004Q1-2011Q4. Percent (\%) or percentage points (pp); year-on-year (yoy) or yearly average).

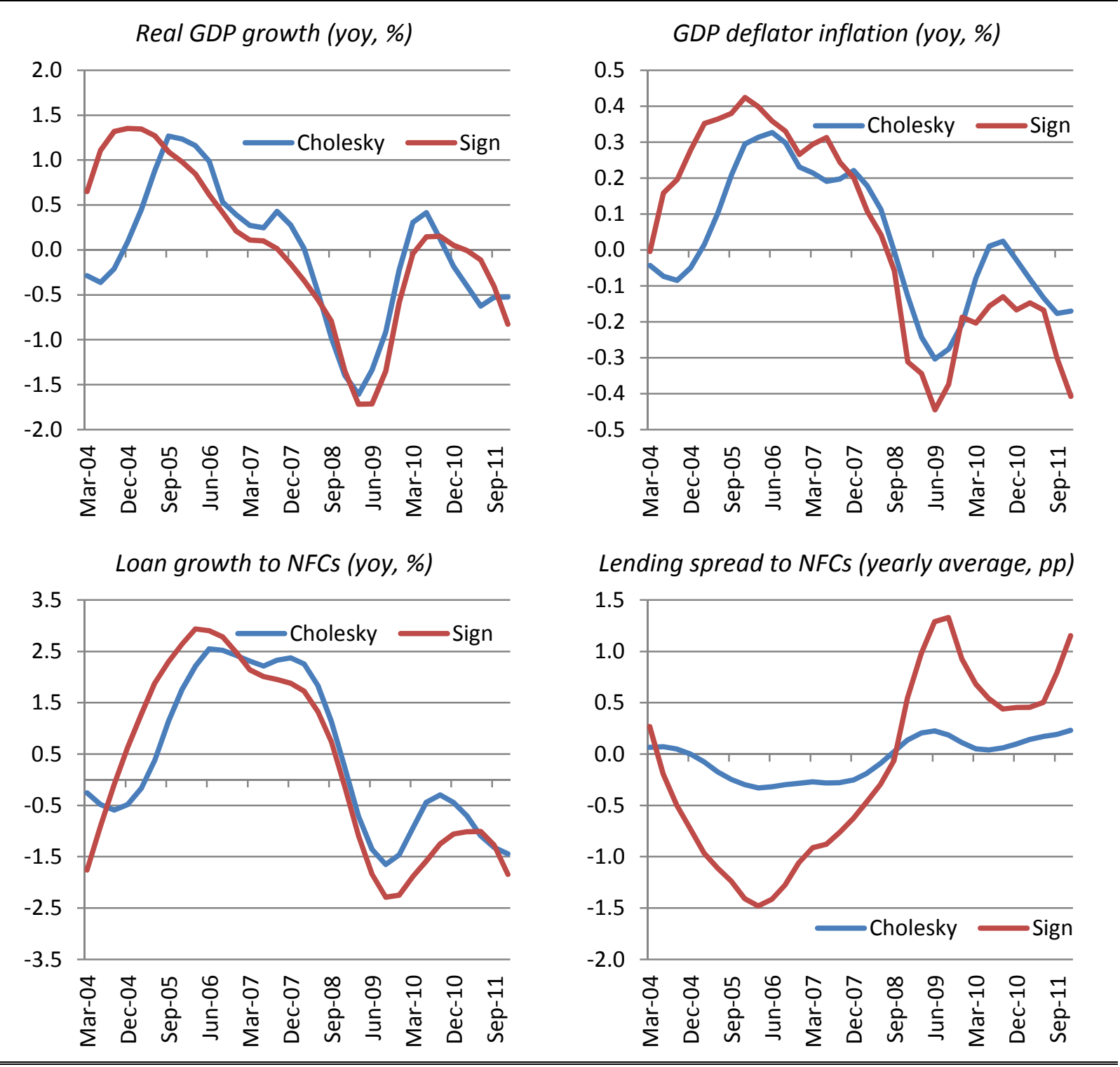

Notes: see Figure 5. 
Fig. 8. Credit supply shock and the April 2012 Bank Lending Survey

(Sample period: 2003Q1-2012Q2).

Panel A: Recursive with 8 countries

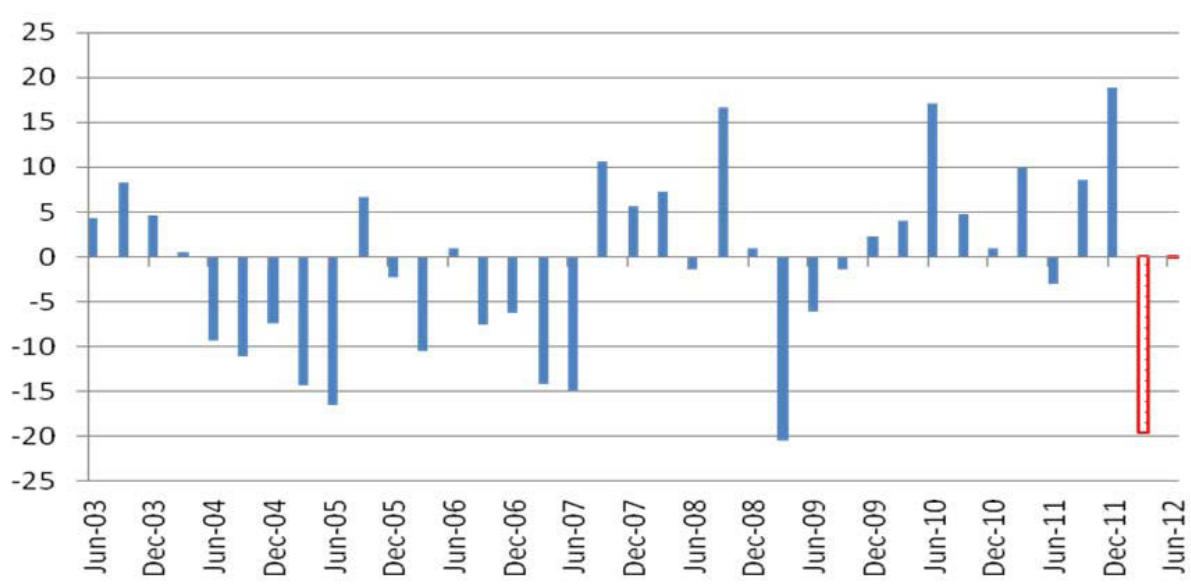

Panel B: Recursive with 11 countries

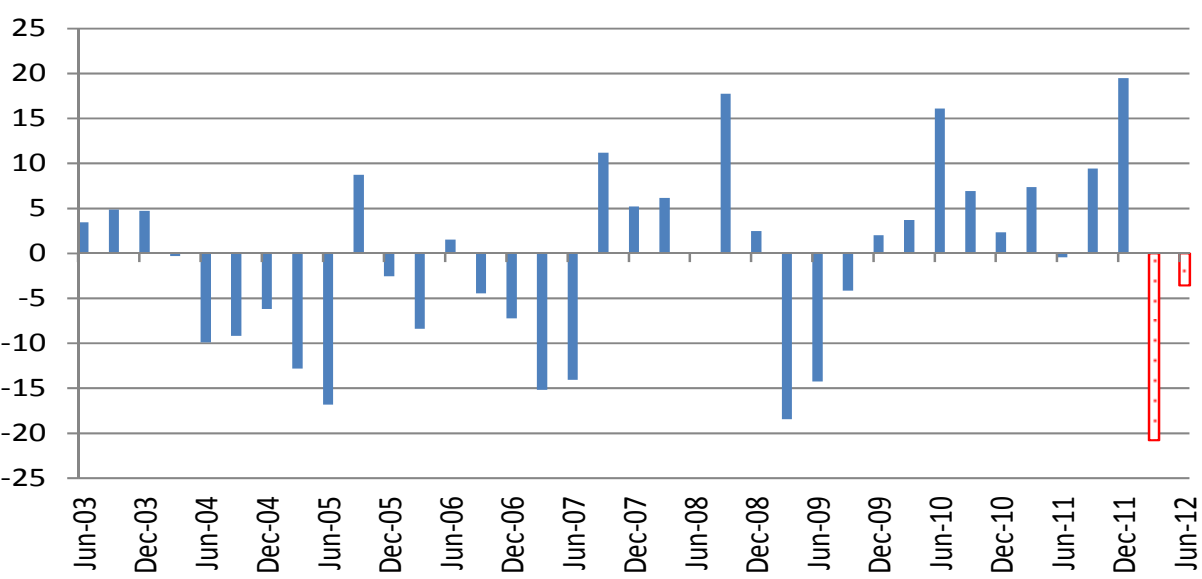

Panel C: Sign restrictions with 11 countries

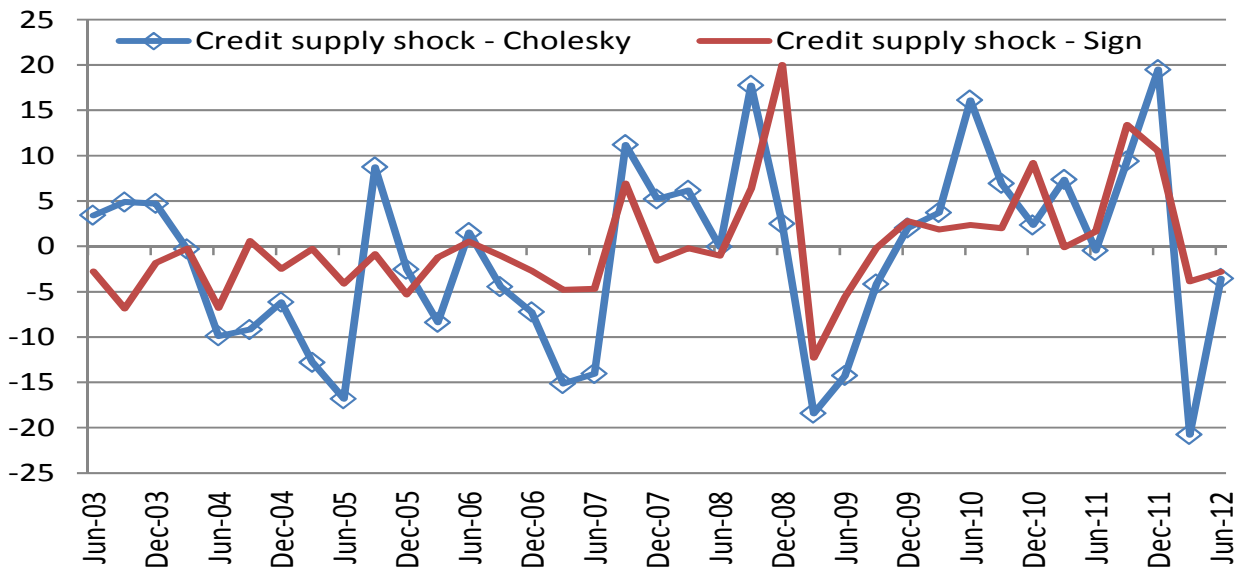

Notes: See Figures 4 and 5. To identify the credit supply shock in 2012Q1 and 2012Q2 we estimate the system applying a Kalman-filter conditional to BLS credit demand and supply factors as reported by the survey respondents in 2012Q1 and as expected by the survey respondents in 2012Q2. A positive bar denotes an unexpected tightening in credit standards. 
Fig. 9. Impact of the 3-year LTROs on the macroeconomy

(Sample period: 2012Q1-2014Q4. Percent (\%) or percentage points (pp)).

$\begin{array}{cccc}\text { Real GDP } & \text { GDP deflator } & \text { Loans to NFCs } & \text { Lending rate spread to } \\ (\%) & (\%) & (\%) & \text { NFCs (pp) }\end{array}$

Panel A - through the April 2012 BLS credit standards ${ }^{1)}$

Panel 8 versus 11 countries (recursive)
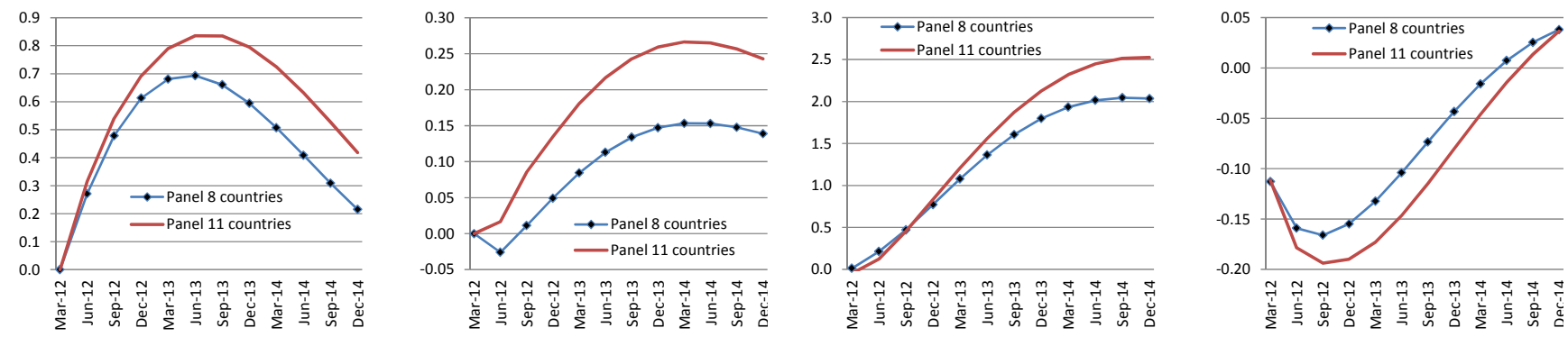

Recursive versus sign restriction (panel with 11 countries)
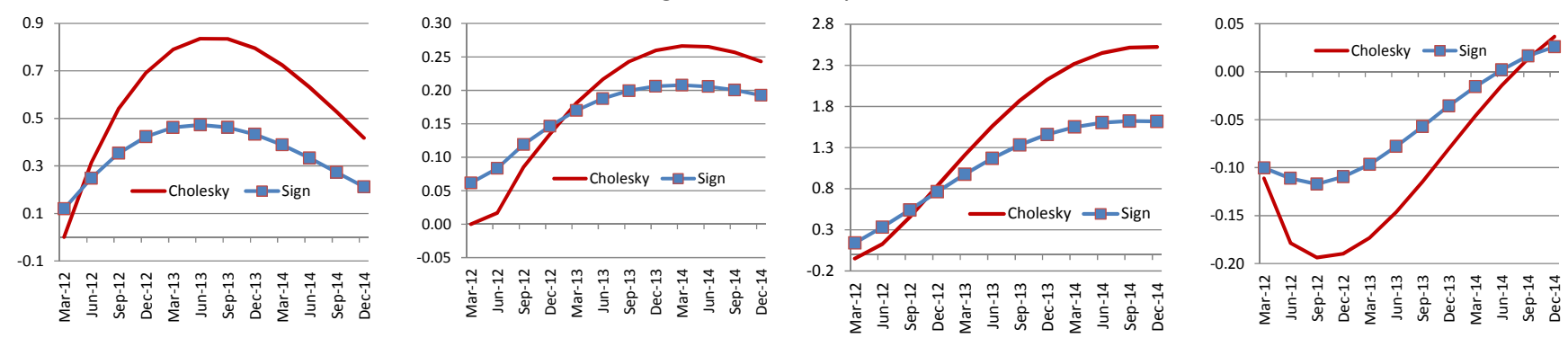

Panel B - through the February 2012 ad-hoc BLS credit standards ${ }^{2}$
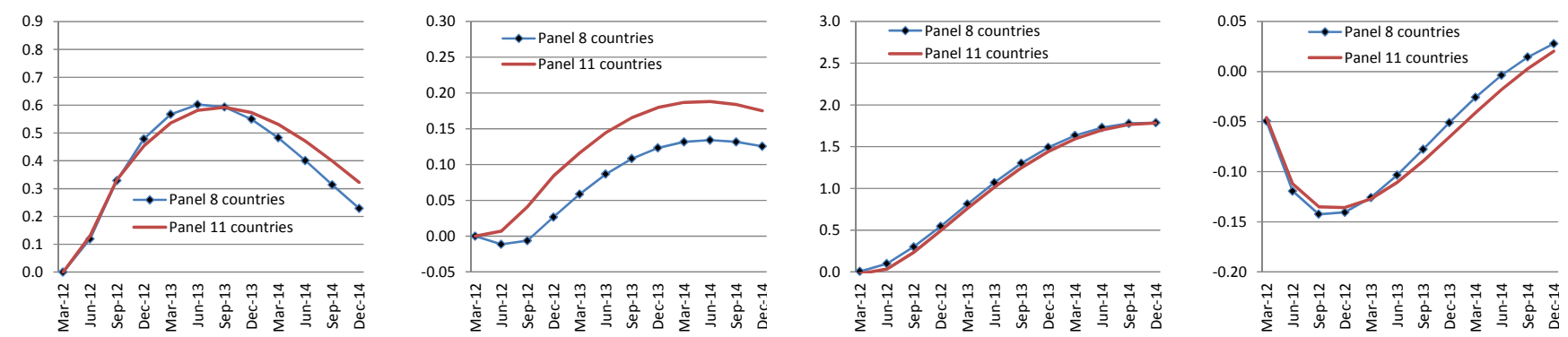

Panel C - through the February 2012 ad-hoc BLS access to funding ${ }^{31}$
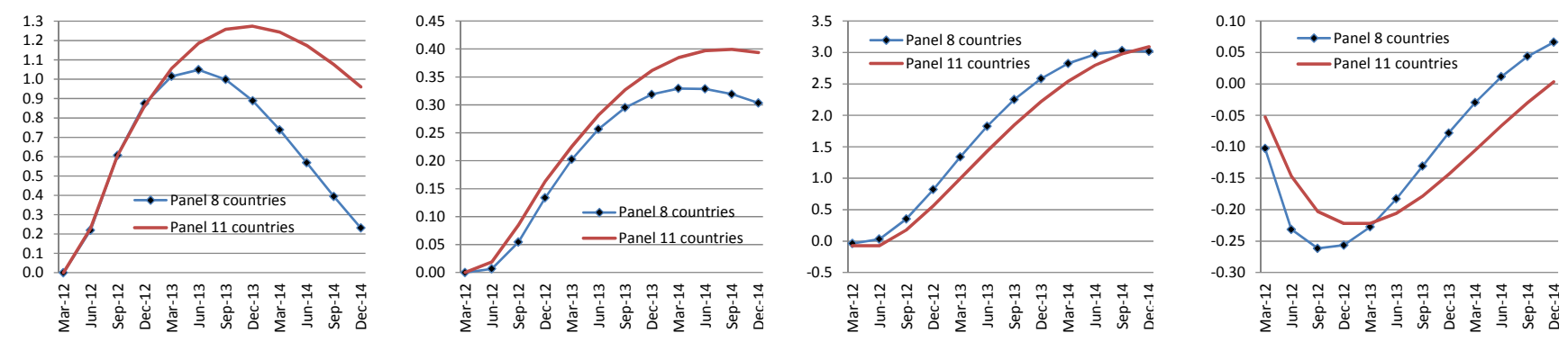

Notes: The VAR specification includes Real GDP growth, GDP deflator inflation, BLS demand factor, BLS supply factor, Lending rate to NFCS minus 3-month OIS, 3-month OIS, and Loan growth to NFCS. The model is estimated over the 2003Q1-2011Q4 period.

Panel A: The credit supply shocks in 2012Q1-2012Q2 are extracted using the one-sided Kalman filter observing the BLS variables only. The impact of the 3-year LTRO results from the simulation of the extracted credit supply shocks. Panel B: The credit supply shock in 2012Q1-2012Q2 is calibrated from the ad-hoc February 2012 BLS. Panel C: The BLS answers on credit standards are replaced in the panel-VAR by the contribution to changes in credit standards attributed to access to funding (both the ability to access market financing, liquidity and capital positions). The entire model is re-estimated, and we assume that the BLS access to funding identifies credit supply following the same identification scheme used to generate Figure 8. 
Fig. 10. The results of the model controlling for the VIX

$\begin{array}{cccc}\text { Real GDP } & \text { GDP deflator } & \text { Loans to NFCS } & \text { Lending rate spread to } \\ (\%) & (\%) & (\%) & \text { NFCs (pp) }\end{array}$

Panel A - Impact of the 3-year LTROs through the February 2012 ad-hoc BLS credit standards

(Sample period: 2012Q1-2014Q4) $)^{1)}$
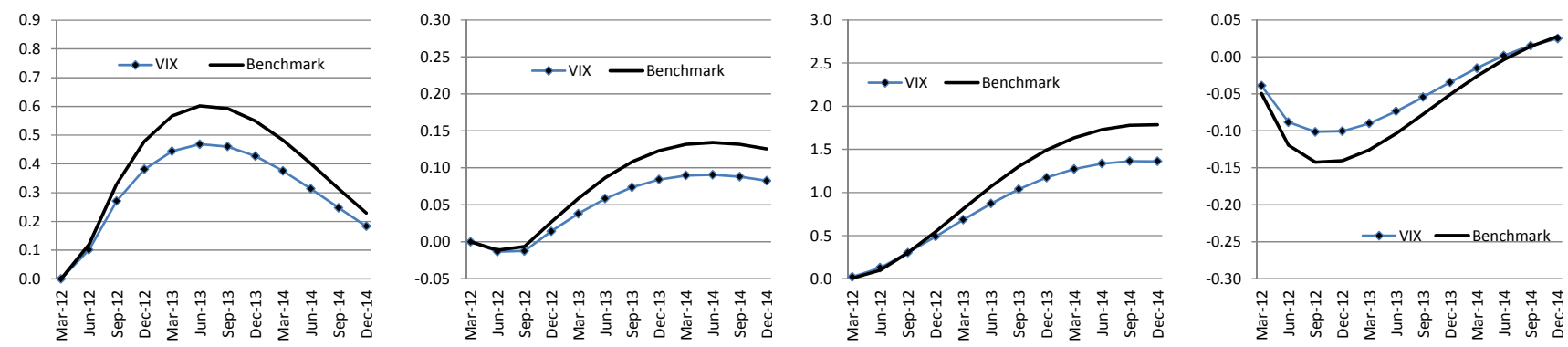

Panel B - Impact of the 3-year LTROs through the April 2012 BLS credit standards

(Sample period: 2012Q1-2014Q4) ${ }^{2)}$
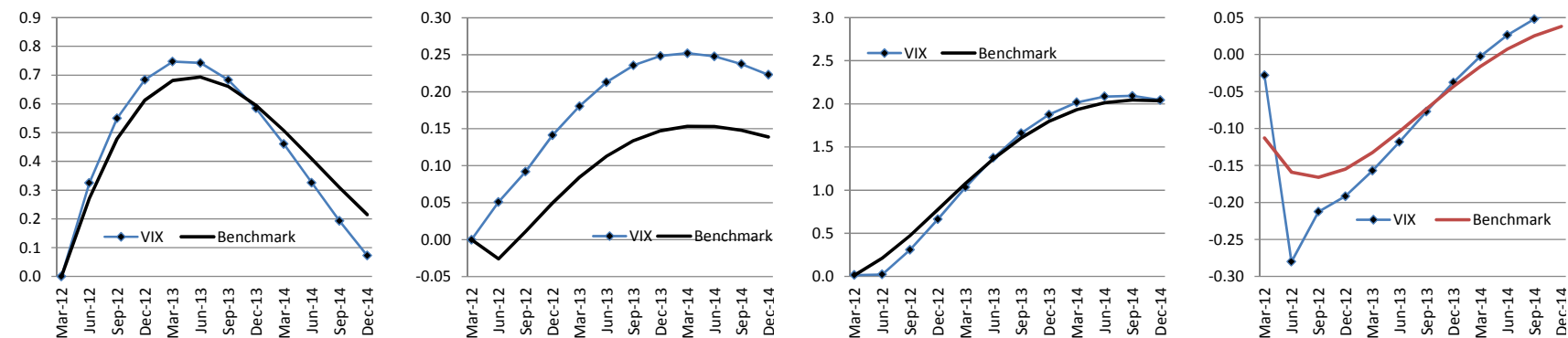

Notes: The benchmark VAR specification includes Real GDP growth, GDP deflator inflation, BLS demand factor, BLS supply factor, Lending rate to NFCS minus 3-month OIS, 3-month OIS, and Loan growth to NFCs. In order to control for the VIX, we include it in the benchmark VAR and order it last. The model is estimated over the 2003Q1-2011Q4 period based on 8 countries.

Panel A : The credit supply shock in 2012Q1-2012Q2 is calibrated from the ad-hoc February 2012 BLS. The impact of the 3-year LTRO results from the simulation of the extracted credit supply shocks.

Panel B: The credit supply in 2012Q1-2012Q2 and the financial shock in 2012Q1 are extracted using the one-sided Kalman filter observing the BLS variables and the VIX only. The credit supply and financial shocks are identified through a standard Choleskidecomposition. The impact of the 3-year LTRO results from the simulation of the extracted credit supply and financial shocks. 
Fig. 11. Interbank credit risk after the 3-year LTROs

(Sample period: 1 Jan. 2007 - 26 Nov. 2012. Basis points.)

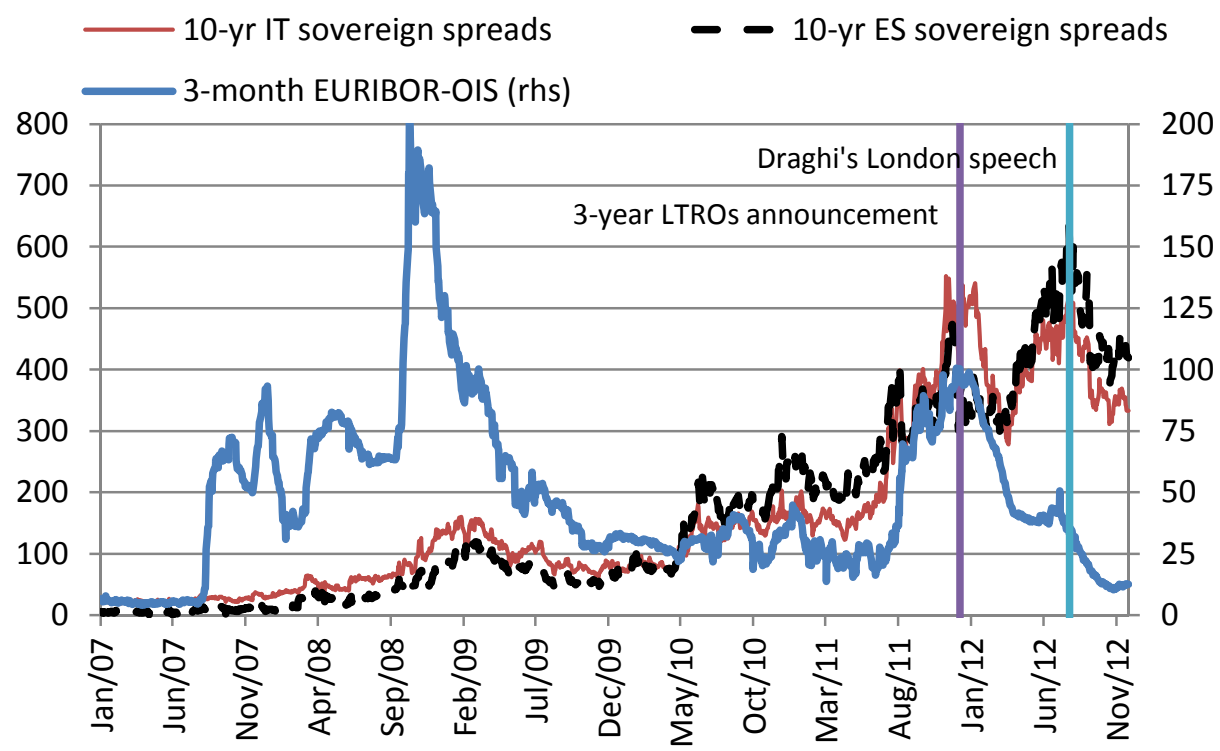

Source: Thomson Reuters.

Notes: 10-yr IT (ES) sovereign spreads is the spread between the 10-year Italian (Spanish) sovereign yield and the 10year Bund. 
Table 1. Covariance analysis: Correlations among regressors

(\%, t-Statistic. Sample period: 2003Q1-2011Q4)

\begin{tabular}{|c|c|c|c|c|c|c|c|c|}
\hline & $\begin{array}{c}\text { Real GDP } \\
\text { growth }\end{array}$ & $\begin{array}{l}\text { Deflator } \\
\text { inflation }\end{array}$ & $\begin{array}{c}\text { BLS } \\
\text { demand } \\
\text { factor }\end{array}$ & $\begin{array}{c}\text { BLS } \\
\text { supply } \\
\text { factor }\end{array}$ & OIS & $\begin{array}{l}\text { Lending } \\
\text { rate to } \\
\text { NFCs-OIS }\end{array}$ & $\begin{array}{l}\text { Loan } \\
\text { growth } \\
\text { to NFCs }\end{array}$ & $\begin{array}{c}\text { Lending } \\
\text { rate to } \\
\text { NFCs }\end{array}$ \\
\hline Real GDP growth & 1.000 & & & & & & & \\
\hline (t-Statistic) & ----- & & & & & & & \\
\hline Deflator inflation & -0.037 & 1.000 & & & & & & \\
\hline (t-Statistic) & -0.630 & ----- & & & & & & \\
\hline BLS demand factor & 0.297 & 0.193 & 1.000 & & & & & \\
\hline (t-Statistic) & 5.258 & 3.318 & ----- & & & & & \\
\hline BLS supply factor & -0.486 & -0.051 & -0.382 & 1.000 & & & & \\
\hline (t-Statistic) & -9.408 & -0.872 & -6.997 & ----- & & & & \\
\hline OIS & 0.175 & 0.266 & 0.185 & 0.185 & 1.000 & & & \\
\hline (t-Statistic) & 3.005 & 4.668 & 3.183 & 3.175 & ----- & & & \\
\hline Lending rate to NFCs-OIS & -0.518 & -0.273 & -0.410 & 0.292 & -0.764 & 1.000 & & \\
\hline (t-Statistic) & -10.229 & -4.798 & -7.607 & 5.172 & -20.021 & ----- & & \\
\hline Loan growth to NFCs & 0.215 & 0.349 & 0.361 & 0.023 & 0.632 & -0.572 & 1.000 & \\
\hline (t-Statistic) & 3.718 & 6.304 & 6.547 & 0.396 & 13.795 & -11.805 & ----- & \\
\hline Lending rate to NFCs & -0.137 & 0.180 & -0.041 & 0.488 & 0.874 & -0.353 & 0.485 & 1.000 \\
\hline (t-Statistic) & -2.331 & 3.094 & -0.696 & 9.454 & 30.370 & -6.391 & 9.373 & ----- \\
\hline
\end{tabular}


Table 2. Panel unit root test

(Sample period: 2003Q1-2011Q4).

\begin{tabular}{|c|c|c|c|c|c|c|c|c|c|c|c|c|c|c|}
\hline & \multicolumn{2}{|c|}{ Real GDP growth } & \multicolumn{2}{|c|}{$\begin{array}{l}\text { GDP Deflator } \\
\text { Inflation }\end{array}$} & \multicolumn{2}{|c|}{ BLS demand factor } & \multicolumn{2}{|c|}{ BLS supply factor } & \multicolumn{2}{|c|}{$\begin{array}{l}\text { Loans to NFC } \\
\text { growth }\end{array}$} & \multicolumn{2}{|c|}{ 3-month OIS } & \multicolumn{2}{|c|}{$\begin{array}{l}\text { Lending rate to } \\
\text { NFCs minus 3- } \\
\text { month OIS }\end{array}$} \\
\hline & Statistic & Prob.** & Statistic & Prob.** & Statistic & Prob.** & Statistic & Prob.** & Statistic & Prob.** & Statistic & Prob.** & Statistic & Prob.** \\
\hline Null Hypothesis: Unit root & \multicolumn{14}{|c|}{ Tests with Individual Unit Root Processes for 8 countries } \\
\hline Im, Pesaran and Shin W-stat ${ }^{1}$ & -4.13 & 0.00 & -8.83 & 0.00 & -5.40 & 0.00 & -3.99 & 0.00 & -2.02 & 0.02 & 0.21 & 0.58 & 0.68 & 0.75 \\
\hline ADF - Fisher Chi-square ${ }^{2}$ & 49.18 & 0.00 & 114.05 & 0.00 & 61.11 & 0.00 & 43.42 & 0.00 & 26.34 & 0.05 & 9.72 & 0.88 & 9.38 & 0.90 \\
\hline PP - Fisher Chi-square ${ }^{3}$ & 48.83 & 0.00 & 130.14 & 0.00 & 71.76 & 0.00 & 41.75 & 0.00 & 41.48 & 0.00 & 5.58 & 0.99 & 9.94 & 0.87 \\
\hline Null Hypothesis: Unit root & \multicolumn{14}{|c|}{ Tests with Common Unit Root Process for 8 countries } \\
\hline Levin, Lin \& Chu t* ${ }^{4}$ & -2.62 & 0.00 & -6.39 & 0.00 & -3.42 & 0.00 & -1.79 & 0.04 & -0.94 & 0.17 & 0.07 & 0.53 & 1.24 & 0.89 \\
\hline Breitung t-stat $^{5}$ & -5.42 & 0.00 & -6.53 & 0.00 & -3.91 & 0.00 & 0.41 & 0.66 & -1.85 & 0.03 & -3.18 & 0.00 & -0.37 & 0.36 \\
\hline \multicolumn{15}{|l|}{ Null Hypothesis: Stationarity } \\
\hline Hadri Z-stat ${ }^{6}$ & 0.45 & 033 & 1.24 & 0.11 & 0.92 & 0.18 & -0.75 & 0.78 & 0.80 & 0.21 & 1.68 & 0.05 & 3.84 & 0.00 \\
\hline Null Hypothesis: Unit root & \multicolumn{14}{|c|}{ Tests with Individual Unit Root Processes for 11 countries } \\
\hline Im, Pesaran and Shin W-stat ${ }^{1}$ & -3.78 & 0.00 & -10.42 & 0.00 & -5.95 & 0.00 & -4.29 & 0.00 & -1.50 & 0.07 & 0.24 & 0.60 & 1.93 & 0.97 \\
\hline ADF - Fisher Chi-square ${ }^{2}$ & 63.08 & 0.00 & 161.51 & 0.00 & 78.83 & 0.00 & 55.94 & 0.00 & 30.64 & 0.10 & 13.36 & 0.92 & 10.25 & 0.98 \\
\hline PP - Fisher Chi-square ${ }^{3}$ & 92.92 & 0.00 & 214.61 & 0.00 & 90.24 & 0.00 & 52.63 & 0.00 & 46.08 & 0.00 & 7.68 & 1.00 & 10.75 & 0.98 \\
\hline Null Hypothesis: Unit root & \multicolumn{14}{|c|}{ Tests with Common Unit Root Process for 11 countries } \\
\hline Levin, Lin \& Chu t ${ }^{* 4}$ & -2.37 & 0.01 & -7.49 & 0.00 & -4.13 & 0.00 & -2.15 & 0.02 & -0.53 & 0.30 & 0.09 & 0.53 & 2.84 & 1.00 \\
\hline Breitung t-stat ${ }^{5}$ & -4.62 & 0.00 & -4.61 & 0.00 & -3.21 & 0.00 & -0.65 & 0.26 & -1.23 & 0.11 & -3.73 & 0.00 & 0.67 & 0.75 \\
\hline Null Hypothesis: Stationarity & & & & & & & & & & & & & & \\
\hline Hadri Z-stat ${ }^{6}$ & 2.41 & 0.01 & 3.15 & 0.00 & 2.33 & 0.01 & 0.09 & 0.47 & 2.18 & 0.01 & 1.97 & 0.02 & 5.27 & 0.00 \\
\hline
\end{tabular}

** Probabilities for Fisher tests are computed using an asymptotic Chi-square distribution. All other tests assume asymptotic normality.

(1) Im, et al (2003). (2) Maddala and Wu (1999). (3) Choi. (2001). (4) Levin, et al. (2002). (5) Breitung (2000). (6) Hadri (2000). 